\title{
Analysis of the mass balance time series of glaciers in the Italian Alps
}

\author{
Luca Carturan $^{1,6}$, Carlo Baroni ${ }^{2,3,6}$, Michele Brunetti ${ }^{4}$, Alberto Carton ${ }^{5,6}$, Giancarlo Dalla Fontana ${ }^{1,6}$, \\ Maria Cristina Salvatore ${ }^{2,6}$, Thomas Zanoner ${ }^{5,6,7}$, and Giulia Zuecco ${ }^{1}$ \\ ${ }^{1}$ Dipartimento Territorio e Sistemi Agro-Forestali, University of Padova, Viale dell'Università 16, \\ 35020, Legnaro, Padova, Italy \\ ${ }^{2}$ Dipartimento di Scienze della Terra, University of Pisa, Via S. Maria 53, 56126, Pisa, Italy \\ ${ }^{3}$ IGG-CNR, Via Giuseppe Moruzzi 1, 56124, Pisa, Italy \\ ${ }^{4}$ ISAC-CNR, Via Gobetti 101, 40129, Bologna, Italy \\ ${ }^{5}$ Dipartimento di Geoscienze, University of Padova, Via Gradenigo 6, 35131, Padova, Italy \\ ${ }^{6}$ Comitato Glaciologico Italiano, Corso Massimo d'Azeglio 42, 10125, Torino, Italy \\ ${ }^{7}$ CNR-IRPI, Strada delle Cacce 73, 10135, Torino, Italy
}

Correspondence to: Luca Carturan (luca.carturan@unipd.it)

Received: 4 October 2015 - Published in The Cryosphere Discuss.: 29 October 2015

Revised: 15 February 2016 - Accepted: 8 March 2016 - Published: 18 March 2016

\begin{abstract}
This work presents an analysis of the mass balance series of nine Italian glaciers, which were selected based on the length, continuity and reliability of observations. All glaciers experienced mass loss in the observation period, which is variable for the different glaciers and ranges between 10 and 47 years. The longest series display increasing mass loss rates, which were mainly due to increased ablation during longer and warmer ablation seasons. The mean annual mass balance $\left(B_{\mathrm{a}}\right)$ in the decade from 2004 to 2013 ranged from -1788 to $-763 \mathrm{~mm}$ w.e. $\mathrm{yr}^{-1}$. Low-altitude glaciers with low range of elevation are more out of balance than the higher, larger and steeper glaciers, which maintain residual accumulation areas in their upper reaches. The response of glaciers is mainly controlled by the combination of OctoberMay precipitations and June-September temperatures, but rapid geometric adjustments and atmospheric changes lead to modifications in their response to climatic variations. In particular, a decreasing correlation of $B_{\mathrm{a}}$ with the JuneSeptember temperatures and an increasing correlation with October-May precipitations are observed for some glaciers. In addition, the October-May temperatures tend to become significantly correlated with $B_{\mathrm{a}}$, possibly indicating a decrease in the fraction of solid precipitation, and/or increased ablation, during the accumulation season. Because most of the monitored glaciers have no more accumulation area, their
\end{abstract}

observations series are at risk due to their impending extinction, thus requiring a replacement soon.

\section{Introduction}

The mass balance of glaciers is a key variable for monitoring strategies of the Earth climate system because it is the direct and undelayed response of glaciers to atmospheric conditions. Other reactions of glaciers to climatic changes, such as the fluctuations of the front, are more easy and immediate to measure but represent indirect, delayed and filtered signals (WGMS, 2008; Zemp et al., 2005).

The direct glaciological method (Østrem and Brugman, $1991)$ is the standardized method in worldwide glacier monitoring strategies. This method consists of in situ measurements of the surface accumulation and ablation, taken at single points and then extrapolated and integrated to yield the glacier-wide surface mass balance (Kaser et al., 2003; Cogley et al., 2011). The World Glacier Monitoring Service (WGMS) collects and publishes mass balance data of glaciers obtained by the glaciological method as part of global climate-related observation systems (Zemp et al., 2009; WGMS, 2012, 2013, and earlier issues). 
Table 1. Physical characteristics of the Italian glaciers with the mass balance series analyzed in this study (year 2006, NextData - DATAGRALP project: http://www.nextdataproject.it/?q=en/content/special-project-datagralp, last access: 27 September 2015; Salvatore et al., 2015).

\begin{tabular}{|c|c|c|c|c|c|c|c|c|}
\hline Glacier & $\begin{array}{l}\text { Geographic } \\
\text { area }\end{array}$ & $\begin{array}{l}\text { Area } \\
\left(\mathrm{km}^{2}\right)\end{array}$ & $\begin{array}{l}\text { Minimum } \\
\text { elevation } \\
\text { (ma.s.1.) }\end{array}$ & $\begin{array}{l}\text { Maximum } \\
\text { elevation } \\
\text { (ma.s.l.) }\end{array}$ & $\begin{array}{l}\text { Median } \\
\text { elevation } \\
\text { (ma.s.1.) }\end{array}$ & $\begin{array}{l}\text { Prevailing } \\
\text { aspect }\end{array}$ & $\begin{array}{l}\text { Average } \\
\text { slope }\left(^{\circ}\right)\end{array}$ & $\begin{array}{l}\text { First } \\
\text { survey } \\
\text { year }\end{array}$ \\
\hline Grand Etrèt & Gran Paradiso & 0.47 & 2667 & 3190 & 2894 & $\mathrm{~N}$ & 23 & 2002 \\
\hline Ciardoney & Gran Paradiso & 0.59 & 2855 & 3170 & 3039 & E-NE & 18 & 1992 \\
\hline Fontana Bianca & Ortles-Cevedale & 0.48 & 2889 & 3342 & 3166 & $\mathrm{E}$ & 23 & 1984 \\
\hline Sforzellina & Ortles-Cevedale & 0.29 & 2790 & 3046 & 2868 & NW & 16 & 1987 \\
\hline Lunga & Ortles-Cevedale & 1.86 & 2678 & 3378 & 3128 & $\mathrm{NE}$ & 19 & 2004 \\
\hline Careser & Ortles-Cevedale & 2.39 & 2868 & 3279 & 3069 & S & 11 & 1967 \\
\hline $\begin{array}{l}\text { La Mare } \\
\text { (southern branch) }\end{array}$ & Ortles-Cevedale & 2.16 & 2652 & 3518 & 3215 & $\mathrm{NE}$ & 21 & 2003 \\
\hline Pendente & Val Ridanna & 0.95 & 2621 & 3064 & 2781 & $\mathrm{~S}$ & 15 & 1996 \\
\hline Malavalle & Val Ridanna & 6.92 & 2512 & 3441 & 2971 & SE & 14 & 2002 \\
\hline
\end{tabular}

The European Alps are one of the regions of the world with the highest density of glaciers that are subject to mass balance observations: 25 glaciers have ongoing and continuous mass balance series with at least 10 years of observations, and 11 of them are longer than 30 years (http://www.wgms. ch/metadatabrowser.html, last access: 27 September 2015). In the Italian Alps, nine glaciers have ongoing and continuous mass balance series longer than 10 years, and only one glacier (the Careser Glacier) has a series longer than 30 years.

The mass balance series of the glaciers in the Italian Alps have not yet been reviewed and analyzed jointly. The Italian glaciers may have a peculiar behavior compared to the glaciers from other regions of the European Alps because of their southern locations in the Alps, the differences in glacier characteristics, climatic features and trends of meteorological variables (Brunetti et al., 2006, 2009; Auer et al., 2007). Differences may occur in the response of the glaciers in different sub-regions of the Italian Alps or with different characteristics, which have not been recognized. It is also interesting to highlight possible feedbacks in the response of Italian glaciers to atmospheric changes.

Therefore, this work aims to (i) analyse and compare the direct mass balance series of the glaciers in the Italian Alps, (ii) understand the behavior of the measured glaciers in relation to the observed climatic trends and (iii) highlight possible future requirements for the mass balance monitoring strategy in the Italian Alps.

\section{Available mass balance series}

In this work, we analyze the glaciers with at least 10 years of continuous and ongoing mass balance measurements, which were obtained using the direct glaciological method and published in peer-reviewed journals or in WGMS publications (CGI, 1914-1977 and 1978-2011; Baroni et al., 2012, 2013,
2014; WGMS, 2012, 2013, and earlier issues). "Continuous" indicates the series with data gaps $<10 \%$, and "ongoing" indicates that the mass balance observations have been performed in the last 2 years (i.e., the 2012 and 2013 hydrological years). These criteria ensure the comparability of the series, a sufficient length in the temporal analyses and reliability of the measurements and calculations.

Nine monitored glaciers fulfil these characteristics in the Italian Alps and are clustered in three geographic areas (Fig. 1). The two monitored glaciers in the Gran Paradiso Group (Western Alps), i.e., Grand Etrèt (since 2002) and Ciardoney (since 1992), are rather small $\left(\operatorname{area}<1 \mathrm{~km}^{2}\right)$ and have low mean elevations and low range of elevation (Table 1). Snowfall is the prevailing feeding source, but wind-borne snow and avalanching also contribute to snow accumulation.

The longest series of mass balance measurements in the Italian Alps has been collected on the Careser Glacier, in the Ortles-Cevedale (Eastern Alps, Fig. 1) since 1967. Currently, this glacier is undergoing rapid shrinking and fragmentation in smaller units. It is characterized by a flat surface, prevailing southern exposure, quite low mean elevation and feeding by snowfall. Its area decreased from $5 \mathrm{~km}^{2}$ in 1967 to $1.6 \mathrm{~km}^{2}$ in 2012 (Carturan et al., 2013a). In the 1980s, observations started in two other glaciers of the Ortles-Cevedale: Fontana Bianca and Sforzellina. These two small mountain glaciers (area $<0.5 \mathrm{~km}^{2}$ ) have different characteristics: Fontana Bianca is rather steep with negligible debris cover and mainly fed by snowfall, whereas Sforzellina is flatter, debris-covered in its lower part and fed by avalanches in its upper part. In the 2000s, mass balance observations began in the Lunga Glacier and in the southern branch of La Mare Glacier, which are larger valley glaciers $\left(1.9\right.$ and $2.2 \mathrm{~km}^{2}$, respectively) that reach higher elevations (3378 and $3518 \mathrm{~m}$, respectively) and mainly fed by snowfall.

In Val Ridanna (Breonie Occidentali Group, Eastern Alps, Fig. 1), the measurements began in 1996 in the Pendente 


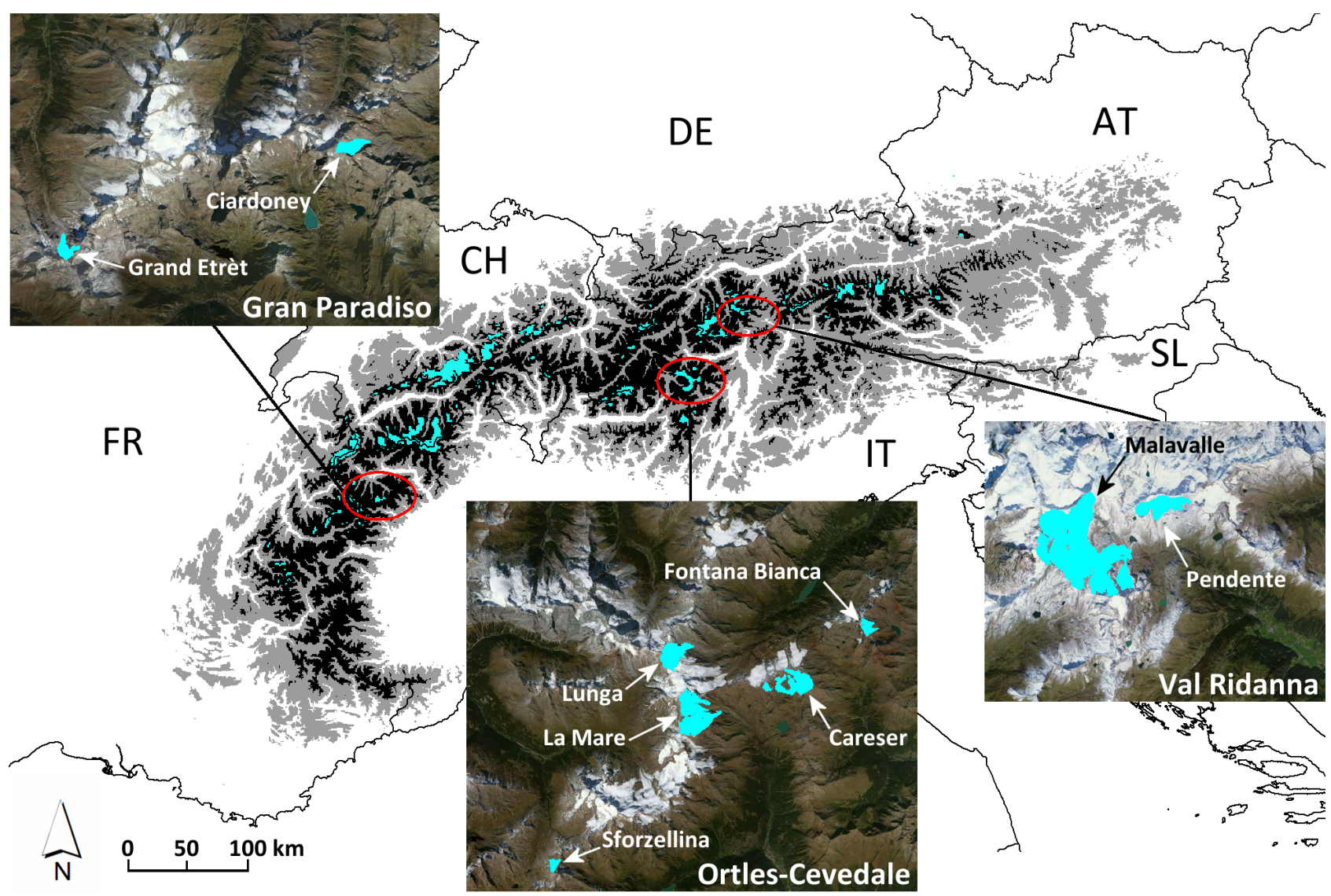

Figure 1. Geographic setting of the glaciers with mass balance measurements analyzed in this work (Microsoft ${ }^{\circledR}$ Bing $^{\mathrm{TM}} \mathrm{Maps}$ ).

Glacier and were extended to the Malavalle Glacier in 2002. The first glacier is a $0.9 \mathrm{~km}^{2}$ wide mountain glacier, characterized by a flat surface, low mean elevation, southern exposure and significant accumulation from wind-borne snow. The second glacier is a much larger $\left(6.9 \mathrm{~km}^{2}\right)$ valley glacier with higher mean and maximum elevation and mainly fed by snowfall.

\section{Methods}

\subsection{Mass balance measurements and calculations}

Point measurements of the annual mass balance in the ablation area consist of repeated readings of ablation stakes, which are made of aluminium, wood or plastic and drilled into the ice/firn using hand drills or steam drills. In the accumulation area, the depth of the snow at the end of the ablation season is measured using hand probes, and its density is determined in snow pits. Snow depth soundings and density measurements in the snow pits or by hand coring devices are also used for winter mass balance measurements, which are performed on all glaciers except Sforzellina. The summer mass balance is derived by subtracting the winter mass balance from the annual mass balance.
The density of measuring points varies among different glaciers in relation to their extent, accessibility and complexity of the mass balance distribution (Fig. 2). The ablation stake density ranges from 4 points $\mathrm{km}^{-2}$ (Malavalle Glacier) to 45 points $\mathrm{km}^{-2}$ (Sforzellina Glacier). The density of snow depth soundings for the winter mass balance determination ranges from 15 points $\mathrm{km}^{-2}$ (Malavalle Glacier) to 142 points $\mathrm{km}^{-2}$ (Fontana Bianca Glacier).

Point measurements are interpolated and extrapolated to the entire area of the glaciers using different procedures. In the Grand Etrèt and Ciardoney glaciers, each ablation stake is assumed representative of a specific part of the glacier, where the mass balance distribution is assumed homogeneous. Then, a weighted mean is calculated, using the area of the homogeneous parts into which the glacier is subdivided as weights (http://www.pngp.it/, last access: 27 September 2015; http://www.nimbus.it/, last access: 27 September 2015). In Malavalle and Pendente glaciers, the area is divided into "sub-catchments", and for each sub-catchment, a linear regression of point balances versus altitude is calculated and used for the spatialization (http://www.provinz.bz. it/wetter/glacierreport.asp, last access: 27 September 2015). In Careser Glacier, the even distribution of the mass balance and good coverage of measurement points enable the 

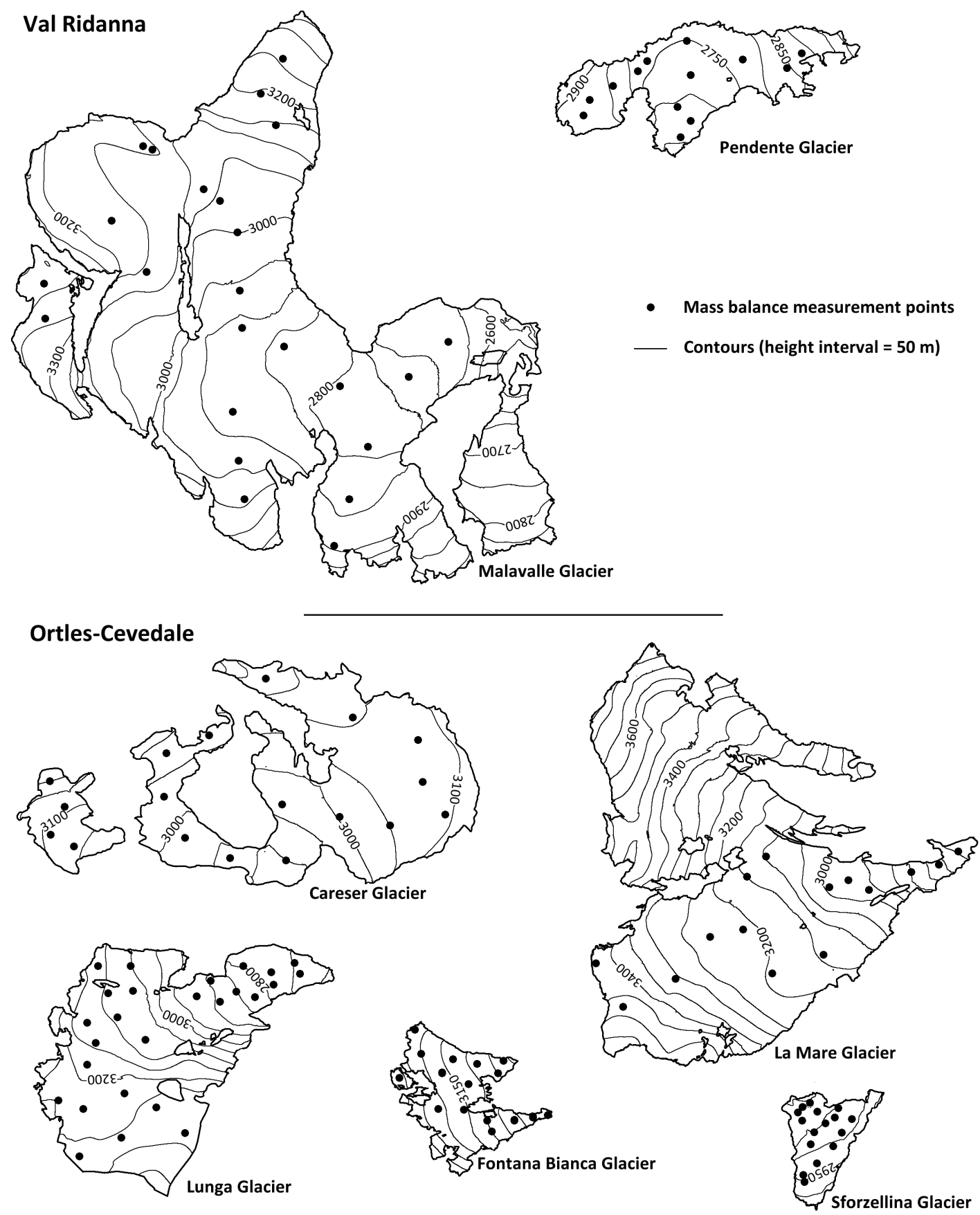

\section{Gran Paradiso}
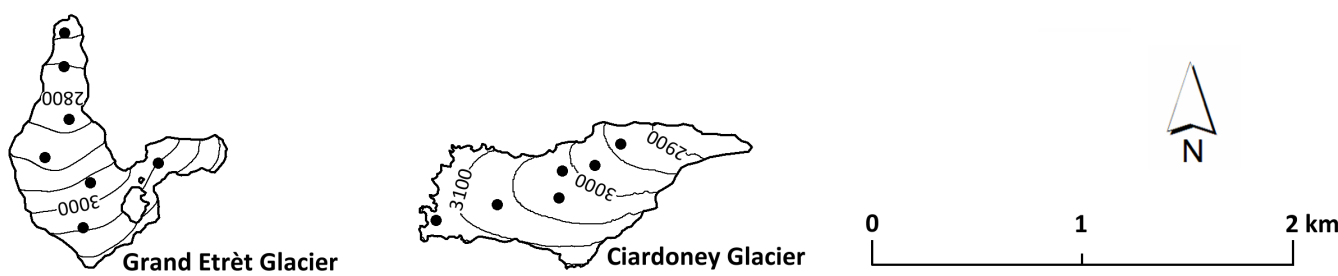

Figure 2. Surface topography and measurement network of the nine glaciers analyzed in this study. 
use of automatic interpolation algorithms (Spatial Analyst Tools) in the ESRI-ArcGIS software. Manual drawing of balance isolines is used for the remaining Sforzellina, Fontana Bianca, La Mare and Lunga glaciers (Catasta and Smiraglia, 1993; Cannone et al., 2008; http://www.provinz.bz.it/wetter/ glacierreport.asp; Carturan, unpublished data). The measurements are performed close to the time of maximum and minimum mass balance during the year, when the glacier and atmospheric conditions are favorable for field surveys. The "floating-date" time measurement system is used for all glaciers (Cogley et al., 2011).

Typical random errors reported in the literature for glacierwide mass balance estimates obtained with these methods are

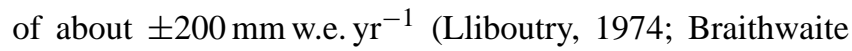
and Olesen, 1989; Cogley and Adams, 1998; Cogley, 2009). The accuracy indicated by the investigators carrying out mass balance measurements in the nine Italian glaciers range between \pm 0.05 and $\pm 0.30 \mathrm{~m}$ w.e. $\mathrm{yr}^{-1}$ (WGMS, 2015; Carturan, unpublished data). Assessments based on the comparison between the direct and the geodetic mass balance have been published for the Careser, La Mare and Lunga glaciers, indicating that the discrepancy between the two methods is lower than the lowest detectable bias (following Zemp et al., 2013), and revealing that a calibration of the direct mass balance results is not required (Carturan et al., 2013a; Galos et al., 2015; Carturan, unpublished data).

\subsection{Meteorological series}

The climatic variables used in this work consist of synthetic records of the monthly mean temperature and total monthly precipitation, which are obtained for the center of the three main geographic areas described in Sect. 2, using the procedure reported in Brunetti et al. (2012). Starting from sparse meteorological data recorded at meteorological stations, the synthetic meteorological series are generated using the anomaly method (New et al., 2000; Mitchell and Jones, 2005). This method is based on the assumption that the spatiotemporal structure of the signal of a meteorological variable over a given area can be described by the superimposition of two fields: the climatological normals over a given reference period (i.e., the climatologies) and the departures from them (i.e., the anomalies). The climatologies are linked to the geographic features of the territory and characterized by remarkable spatial gradients; the departures are linked to the climate variability and change, and they are generally characterized by higher spatial coherence.

Under this assumption, the climatologies and anomalies can be reconstructed in completely independent manners and based on different data sets. For climatologies, the priority is the high spatial resolution, and a short time span (few decades) is sufficient. A lower spatial resolution is sufficient for the anomalies, but more importance is given to the data quality and availability of long records. Thus, all series that were used for the anomaly component were subjected to homogenization.

The interpolation methods are different for the two components. The climatologies, which are characterized by high spatial gradients, were reconstructed using the procedure described in Brunetti et al. (2014), exploiting the relationship between the meteorological variable and the physical characteristics of the terrain. The anomalies, which are characterized by higher spatial coherence, were reconstructed using weighted averages as described in Brunetti et al. (2006). The weights are horizontal and vertical distance weighting functions, with the addition of an angular weight that accounts for the anisotropy in the distribution of stations around the sites. Finally, the two fields were superimposed to obtain the temporal series in absolute values for each site.

\subsection{Analyses of the mass balance and meteorological series}

The time series of annual mass balance $\left(B_{\mathrm{a}}\right)$, winter mass balance $\left(B_{\mathrm{w}}\right)$, summer mass balance $\left(B_{\mathrm{s}}\right)$ and accumulation area ratio (AAR, i.e., the ratio of the area of the accumulation zone to the area of the glacier) were analyzed and compared to highlight the possible trends, break points, common behavior and peculiarities of single glaciers and/or single years. To highlight the systematic differences among the glaciers, the mean values of $B_{\mathrm{a}}, B_{\mathrm{w}}, B_{\mathrm{s}}$ and AAR were calculated in the common period of observation from 2004 to 2013. The decadal means of $B_{\mathrm{a}}$ for the Italian glaciers were compared to the decadal means for a sample of nine representative glaciers of the European Alps (Zemp et al., 2005). The correlations among the $B_{\mathrm{a}}$ series of different glaciers and among $B_{\mathrm{a}}$ of single glaciers with the respective series of $B_{\mathrm{w}}$ and $B_{\mathrm{S}}$ were subsequently computed to identify possible groups of glaciers with similar behaviors and to understand the relative importance of the seasonal components of mass balance.

Linear trends and moving averages were calculated for the time series of air temperature and precipitation to highlight the climatic drivers of the observed glacier changes. In particular, we focused on the precipitation of the accumulation season, from October to May (Oct-May), and on the air temperature of the ablation season, from June to September (Jun-Sep) (Pelto, 2008; Carturan et al., 2013b), computing their correlation with $B_{\mathrm{a}}$ and performing multiple linear regression analyses. For the four glaciers with the longest mass balance series (Careser, Fontana Bianca, Sforzellina and Ciardoney), we performed a moving correlation analysis of $B_{\mathrm{a}}$ versus the seasonal and annual temperature and precipitation to recognize possible changes and/or trends in their response and sensitivity to climatic fluctuations, e.g., ascribable to geometric adjustments. A correlation analysis of $B_{\mathrm{w}}, B_{\mathrm{s}}$ and $B_{\mathrm{a}}$ versus the seasonal (December-February and October-May) and annual mean North Atlantic Oscillation (NAO, http://www.cpc.ncep.noaa.gov/products/precip/ CWlink/pna/new.nao.shtml, last access: 11 February 2016) 
index was performed, using the mass balance data of glaciers from Italy and from other nations of the European Alps. Fiveyear (i.e., current \pm 2 years) triangular moving averages have been applied to the time series before correlation analyses to highlight possible convergent low-frequency patterns which are not detectable at the annual scale.

\section{Results and discussion}

\subsection{Analysis of mass balance series}

\subsubsection{Annual balance}

The longest available series for the glaciers in the Italian Alps clearly show a trend towards more negative $B_{\mathrm{a}}$ in the observation period (Fig. 3) and one or two change points, which were identified using the "Changepoint" $\mathrm{R}$ package (Killick and Eckley, 2014). In particular, the series of Careser Glacier shows three phases: (i) the period from 1967 to 1980 with near-equilibrium conditions (mean $B_{\mathrm{a}}=-132 \mathrm{~mm}$ w.e. $\mathrm{yr}^{-1}, \mathrm{SD}=540 \mathrm{~mm}$ w.e.), (ii) the period from 1981 to 2002 with imbalanced conditions (mean $B_{\mathrm{a}}=-1192 \mathrm{~mm}$ w.e. $\mathrm{yr}^{-1}, \mathrm{SD}=517 \mathrm{~mm}$ w.e.) and (iii) the period after 2002 with stronger imbalance (mean $B_{\mathrm{a}}=-1926 \mathrm{~mm}$ w.e. $\mathrm{yr}^{-1}, \mathrm{SD}=725 \mathrm{~mm}$ w.e.). The transition of 2002-2003 is also observable for the Fontana Bianca, Sforzellina and Pendente glaciers, whose measurements started in the $1980 \mathrm{~s}$ and $1990 \mathrm{~s}$. Their mean $B_{\mathrm{a}}$ values changed from $-599,-868$ and $-703 \mathrm{~mm}$ w.e. $\mathrm{yr}^{-1}$ before 2002 to $-1257,-1471$ and $-1308 \mathrm{~mm}$ w.e. $\mathrm{yr}^{-1}$ after 2002, respectively. This transition is less obvious for the Ciardoney Glacier, which experienced a notably negative mass balance already in 1998 and 1999.

\subsubsection{Seasonal balance and AAR}

The $B_{\mathrm{w}}$ and $B_{\mathrm{S}}$ series have some gaps but suggest that the increased mass loss rates were mainly ascribable to increased ablation (and associated positive feedbacks) instead of decreased snow accumulation. These results are consistent with previous works which indicate that the mass changes of the glaciers in the Alps, at the annual and decadal scale, are mainly driven by the summer balance (e.g., Schoner et al., 2000; Vincent et al., 2004; Zemp et al., 2008; Huss et al., 2015).

The AAR series show that the accumulation area almost vanished from all glaciers in the 2000s except the years 2001, 2010 and 2013, when several glaciers were close to balancedbudget conditions mainly as a result of the increased $B_{\mathrm{w}}$. In these years, the highest increase in AAR occurred in the Fontana Bianca Glacier, which is steep and exposed to the east. In contrast, the AAR did not significantly increase in the neighboring Careser Glacier, which is flatter and mainly exposed to the south (Table 1). This behavior is uncommon for flat glaciers because they should be more sensitive to vari- ations of the equilibrium line altitude (ELA) than the steeper glaciers (Benn and Evans, 2010) and reveals that the Careser Glacier is almost completely below the current ELA, even in the years of ELA minima. La Mare and Malavalle glaciers, which are larger and cover a wider elevation range (Table 1), show more persistent accumulation areas, although their size is too small to ensure balanced-budget conditions.

The $B_{\mathrm{a}}$ and $B_{\mathrm{s}}$ values of different glaciers tend to diverge in years with largely negative mass balance and converge in years closer to equilibrium (1993, 2001, 2010 and 2013; Fig. 3). Reinforcing processes and feedbacks likely amplify the differences among the glaciers in imbalanced years, particularly the decrease in the glacier-average albedo caused by the early disappearance of snow from low-lying, flat and less topographic-shielded glaciers and by the accumulation of dust and debris on the surface. $B_{\mathrm{w}}$ also shows the alternation of years with small/large variability among the glaciers, but this behavior cannot be clearly related to the magnitude of the snow accumulation, as observed in the two high-accumulation years 2009 (high variability) and 2013 (low variability). In this case, the spatial variability of the precipitation during the accumulation season, which is larger than the spatial variability of air temperature in the ablation season, determines the interannual variability of $B_{\mathrm{w}}$ for single glaciers, which is further controlled by snow redistribution processes. Snow redistribution appears more effective for the Pendente, Grand Etrèt and Ciardoney glaciers, leading to over-accumulation in snow-rich winters (e.g., in 2009) and larger interannual variability of $B_{\mathrm{w}}$. Correlation coefficients calculated between $B_{\mathrm{w}}$ and Oct-May precipitations range between 0.73 and 0.78 ; they are significant at the 0.05 level only for Careser, La Mare, Lunga, Fontana Bianca and Malavalle, while they are not statistically significant for Pendente, Grand Etrèt and Ciardoney, in line with the hypothesized higher importance of snow redistribution processes in these three glaciers.

\subsubsection{Comparisons in the common period from 2004 to 2013 and spatial representativeness}

In the period from 2004 to 2013, significantly higher $B_{\mathrm{w}}$ is observed for Pendente and Grand Etrèt, compared with the other glaciers in the same geographic area (Table 2), explaining the persistence of these two ice bodies at such low altitude (Table 1). In the same period, the Careser Glacier had the lowest average $B_{\mathrm{a}}$ and AAR, whereas the Malavalle and La Mare glaciers had the highest average $B_{\mathrm{a}}$, $B_{\mathrm{S}}$ and AAR, retaining accumulation areas in their upper parts. However, the mean AARs were remarkably low for all analyzed glaciers and far from balanced-budget conditions $\left(\mathrm{AAR}_{0}=0.55-0.58\right.$; Dyurgerov et al., 2009; Mernild et al., 2013). Overall, low-altitude and flat glaciers with low range of elevation are more out of balance than the steeper glaciers at higher altitude with higher range of elevation, as acknowledged in various other studies (e.g., Furbish and Andrews, 

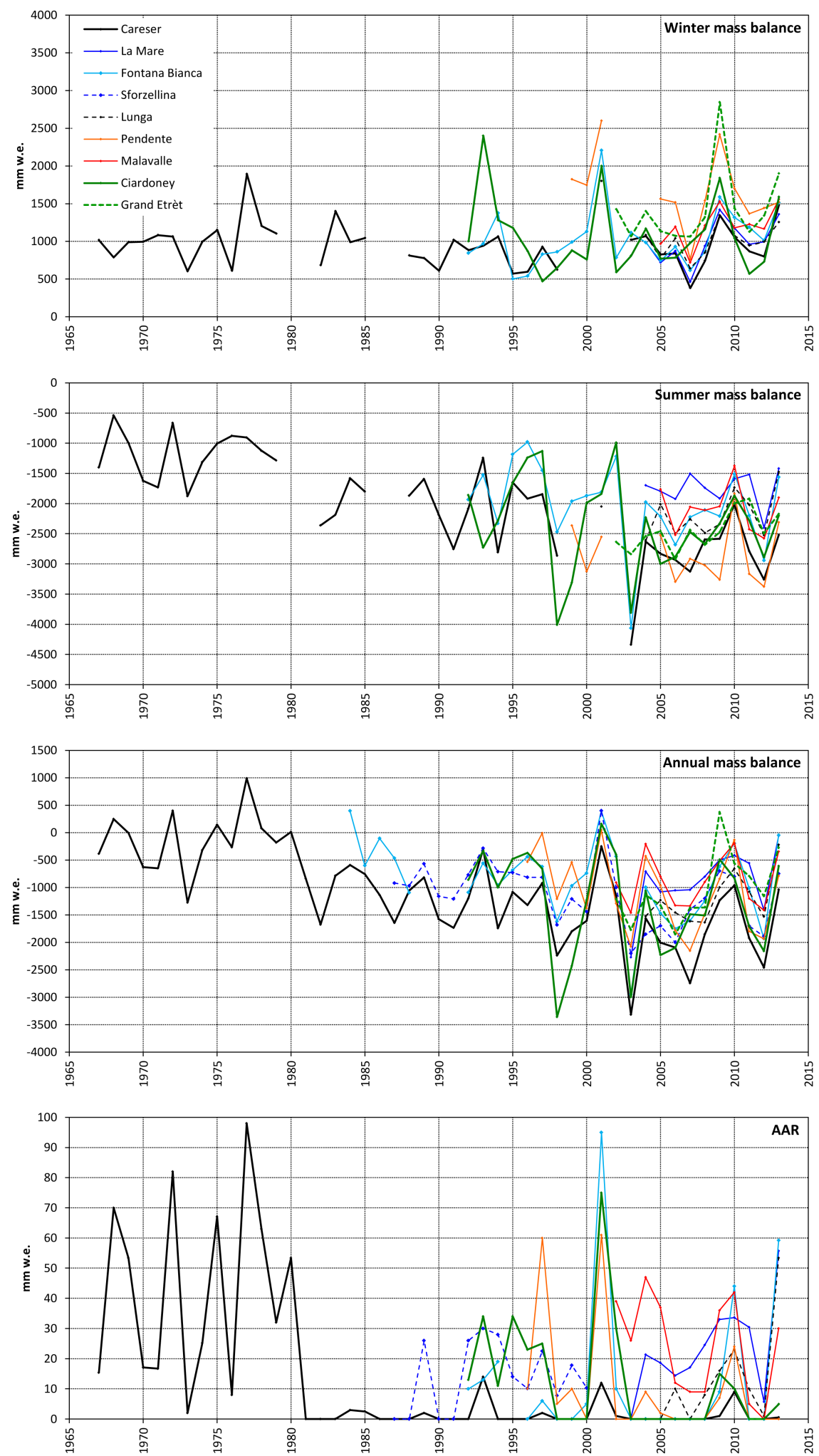

Figure 3. Time series of $B_{\mathrm{W}}, B_{\mathrm{s}}, B_{\mathrm{a}}$ and AAR for the nine Italian glaciers analyzed. 
Table 2. Mean values (and standard deviation in brackets) of $B_{\mathrm{W}}, B_{\mathrm{S}}, B_{\mathrm{a}}$ and AAR for nine Italian glaciers in the period from 2004 to 2013 (Car is Careser, FB is Fontana Bianca, Pen is Pendente, Cia is Ciardoney, Sfo is Sforzellina, GE is Grand Etrèt, Lun is Lunga, Mar is La Mare, Mal is Malavalle). Values are expressed in mm w.e. except for AAR, which is in percent.

\begin{tabular}{lrrrrrrrrr}
\hline & Car & Mar & FB & Sfo & Lun & Pen & Mal & Cia & GE \\
\hline$B_{\mathrm{W}}$ & 927 & 989 & 1085 & - & 991 & 1537 & 1194 & 1052 & 1472 \\
$(9$ years $)$ & $(330)$ & $(301)$ & $(338)$ & & $(222)$ & $(425)$ & $(256)$ & $(421)$ & $(578)$ \\
\hline$B_{\mathrm{S}}$ & -2740 & -1758 & -2183 & - & -2151 & -2857 & -2087 & -2510 & -2396 \\
$(9$ years $)$ & $(368)$ & $(303)$ & $(457)$ & & $(368)$ & $(525)$ & $(386)$ & $(378)$ & $(321)$ \\
\hline$B_{\text {a }}$ & -1788 & -763 & -1088 & -1399 & -1195 & -1231 & -825 & -1419 & -946 \\
$(10$ years $)$ & $(590)$ & $(395)$ & $(642)$ & $(505)$ & $(466)$ & $(692)$ & $(484)$ & $(646)$ & $(648)$ \\
\hline AAR & 1 & 25 & 11 & - & 12 & 4 & 23 & 3 & - \\
$(10$ years $)$ & $(3)$ & $(14)$ & $(22)$ & & $(16)$ & $(8)$ & $(17)$ & $(5)$ & \\
\hline
\end{tabular}

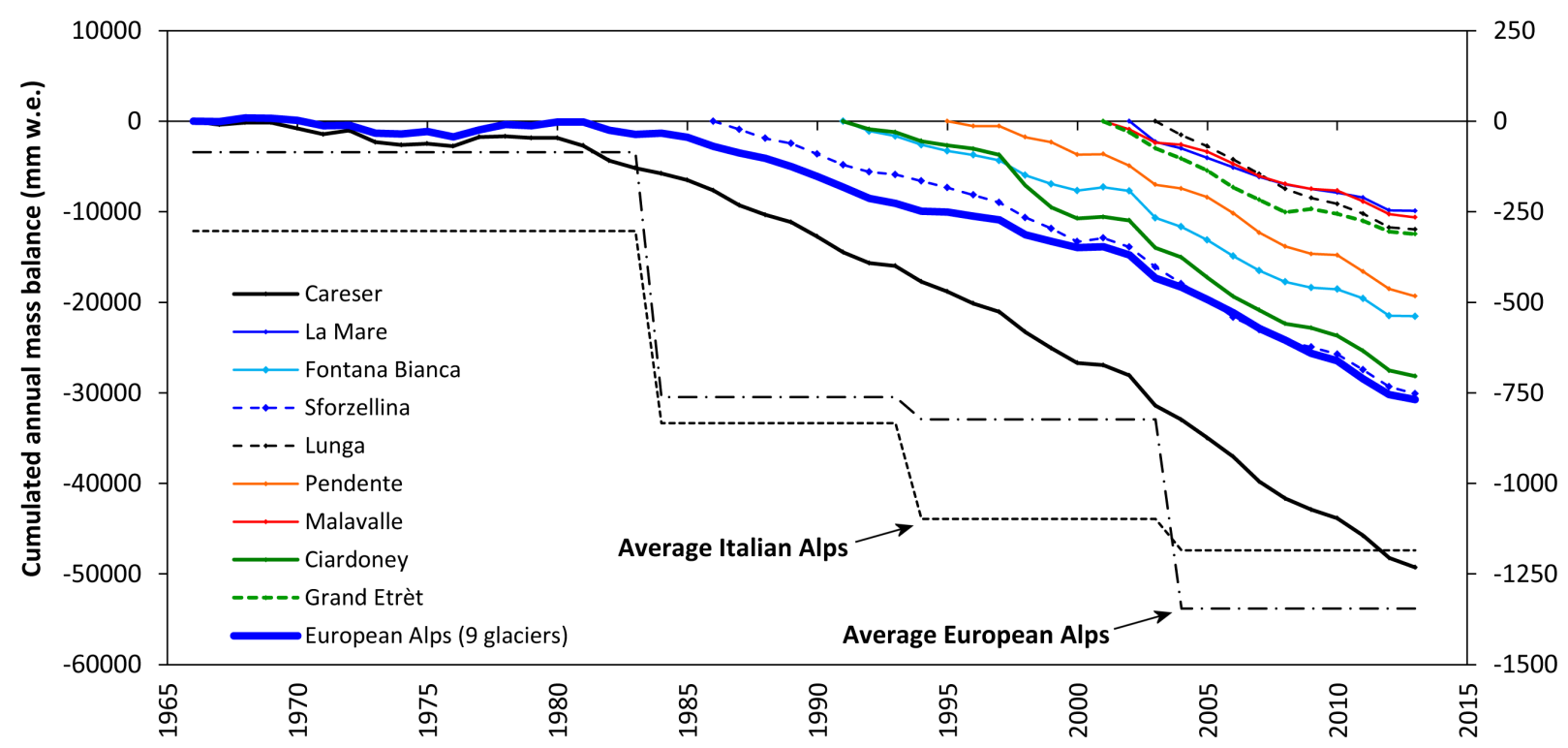

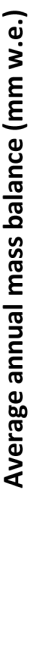

Figure 4. Cumulative mass balance for the nine Italian glaciers and for a set of nine other glaciers representative of the European Alps. Dotted and dashed lines indicate the average $B_{\mathrm{a}}$ for the two groups of glaciers in the periods from 1967 to 1983,1984 to 1993,1994 to 2003 and 2004 to 2013 .

1984; Benn and Evans, 2010; Carturan et al., 2013b; Fischer et al., 2015).

At the regional scale, the spatial representativeness of five Italian mass balance glaciers can be assessed on the basis of the geodetic mass balance calculations performed by Carturan et al. (2013b). In the period from the 1980s to the 2000s, the average geodetic mass balance rate of the 112 glaciers in the Ortles-Cevedale Group has been -0.69 m w.e. $\mathrm{yr}^{-1}$. If we consider the average geodetic mass balance in the same period as an index of the spatial representativeness for single glaciers, we obtain, in decreasing order, (i) La Mare with -0.64 m w.e. $\mathrm{yr}^{-1}$, (ii) Sforzellina with $-0.86 \mathrm{~m}$ w.e. $\mathrm{yr}^{-1}$, (iii) Fontana Bianca with $-0.90 \mathrm{~m}$ w.e. $\mathrm{yr}^{-1}$, (iv) Lunga with $-1.00 \mathrm{~m}$ w.e. $\mathrm{yr}^{-1}$ and (v) Careser with $-1.43 \mathrm{~m}$ w.e. $\mathrm{yr}^{-1}$.
These results confirm that a proper assessment of the spatial representativeness is required when inferring regional-scale mass balance estimates using single glaciers. Geodetic calculations only exist for few areas in the Italian Alps (e.g., Galos et al., 2015) and do not include the other four mass balance glaciers analyzed in this study. Therefore it was not possible to evaluate their spatial representativeness at the regional scale. Similarly, quantitative assessments of the representativeness of all the nine glaciers at the scale of the entire Italian Alps will require further investigations, integrating in situ measurements, remotely sensed observations and numerical modeling (WGMS, 2015). 
Table 3. Correlation matrix of $B_{\mathrm{a}}$ for nine Italian glaciers.

\begin{tabular}{llllllllll}
\hline & Car & FB & Pen & Cia & Sfo & GE & Lun & Mar & Mal \\
\hline Car & 1.00 & & & & & & & & \\
FB & $0.82^{\mathrm{b}}$ & 1.00 & & & & & & & \\
Pen & $0.85^{\mathrm{b}}$ & $0.76^{\mathrm{b}}$ & 1.00 & & & & & & \\
Cia & $0.87^{\mathrm{b}}$ & $0.86^{\mathrm{b}}$ & $0.55^{\mathrm{a}}$ & 1.00 & & & & & \\
Sfo & $0.82^{\mathrm{b}}$ & $0.75^{\mathrm{b}}$ & $0.65^{\mathrm{b}}$ & $0.81^{\mathrm{b}}$ & 1.00 & & & & \\
GE & $0.74^{\mathrm{b}}$ & $0.77^{\mathrm{b}}$ & $0.66^{\mathrm{a}}$ & $0.62^{\mathrm{a}}$ & $0.69^{\mathrm{a}}$ & 1.00 & & & \\
Lun & $0.70^{\mathrm{a}}$ & $0.73^{\mathrm{a}}$ & 0.60 & 0.48 & 0.49 & $0.77^{\mathrm{b}}$ & 1.00 & & \\
Mar & $0.90^{\mathrm{b}}$ & $0.96^{\mathrm{b}}$ & $0.70^{\mathrm{a}}$ & $0.90^{\mathrm{b}}$ & $0.82^{\mathrm{b}}$ & $0.80^{\mathrm{b}}$ & $0.71^{\mathrm{a}}$ & 1.00 & \\
Mal & $0.87^{\mathrm{b}}$ & $0.84^{\mathrm{b}}$ & $0.97^{\mathrm{b}}$ & $0.61^{\mathrm{a}}$ & $0.65^{\mathrm{a}}$ & $0.68^{\mathrm{a}}$ & 0.61 & $0.80^{\mathrm{b}}$ & 1.00 \\
\hline a and ${ }^{\mathrm{b}}$ indicate Spearman correlation coefficients significant at the 0.05 and 0.01 level, respectively. &
\end{tabular}

\subsubsection{Comparison with other glaciers in the European Alps}

The response of Italian glaciers to the climatic conditions of the last decades is similar to that of nine representative glaciers of the entire European Alps (Zemp et al., 2005; Fig. 4), although single glaciers display different mass loss rates (Table 2). The Italian glaciers display $\sim 200-250 \mathrm{~mm}$ w.e. $\mathrm{yr}^{-1}$ more negative $B_{\mathrm{a}}$ until 2002 and $\sim 200 \mathrm{~mm}$ w.e. $\mathrm{yr}^{-1}$ less negative $B_{\mathrm{a}}$ since then. Therefore, it can be assessed that the mean $B_{\mathrm{a}}$ values for the Italian and "European" glaciers are fairly similar. Comparable results were obtained by Huss et al. (2015), who compared the decadal mean $B_{\mathrm{a}}$ of glaciers from France, Switzerland, Austria and Italy. These comparisons may be affected by the loss of spatial representativeness of some glaciers (e.g., Careser in the Italian Alps and Sarennes in the French Alps; Carturan et al., 2013a; Thibert et al., 2013) and by the different subsets of Italian glaciers which are useable in the four different sub-periods. In the last decade, the inclusion of $\mathrm{La}$ Mare and Malavalle glaciers in the Italian subset and the concurrent sharp decrease of $B_{\mathrm{a}}$ for the Sarennes, St. Sorlin and Gries glaciers explain the different behaviors of the two groups of glaciers. However, the smaller Italian glaciers (average area $=1.79 \mathrm{~km}^{2}$ ) may have a shorter response time to climatic changes, adjusting their geometry faster than the larger glaciers (average area $=3.63 \mathrm{~km}^{2}$ ) which are representative of the European Alps (Hoelzle et al., 2003; Abermann et al., 2009). The rapid shrinking and fragmentation of Careser Glacier is a good example: in the last decade, its area has halved, and it completely lost the parts subject to higher ablation (Carturan et al., 2013a). Changes in the general atmospheric circulation and spatial distribution of precipitation could also have played a role and will be discussed in Sect. 4.2.
Table 4. Correlation coefficients of $B_{\mathrm{a}}$ versus $B_{\mathrm{W}}$ and $B_{\mathrm{S}}$.

\begin{tabular}{lcll}
\hline & No. of years & Bw & Bs \\
\hline Car & 40 & $0.46^{\mathrm{b}}$ & $0.94^{\mathrm{b}}$ \\
FB & 22 & 0.24 & $0.84^{\mathrm{b}}$ \\
Pen & 12 & $0.84^{\mathrm{b}}$ & $0.67^{\mathrm{a}}$ \\
Cia & 22 & $0.51^{\mathrm{a}}$ & $0.76^{\mathrm{b}}$ \\
GE & 12 & $0.84^{\mathrm{b}}$ & $0.66^{\mathrm{a}}$ \\
Lun & 10 & $0.64^{\mathrm{a}}$ & $0.69^{\mathrm{a}}$ \\
Mar & 10 & $0.66^{\mathrm{a}}$ & $0.64^{\mathrm{a}}$ \\
Mal & 9 & 0.48 & $0.85^{\mathrm{b}}$ \\
\hline${ }^{\mathrm{a}}$ and \\
significant at the 0.05 and 0.01 level, respectively.
\end{tabular}

\subsubsection{Correlation analyses}

There is a generally high correlation among the $B_{\mathrm{a}}$ values of the analyzed glaciers (Table 3). The series of Careser, Fontana Bianca and La Mare glaciers show a highly significant correlation with most other glaciers, even if they have different characteristics or are far away. In contrast, the Lunga Glacier shows a lower correlation and lower statistical significance with the glaciers of the same mountain group. However, it has the shortest series, and most importantly it does not include the highly negative $B_{\mathrm{a}}$ of 2003 , which certainly increases the correlation among other glaciers. There are notably high correlations in the Ortles Cevedale between Careser and La Mare and between Fontana Bianca and La Mare glaciers. A similarly high correlation is observed between Pendente and Malavalle glaciers in Val Ridanna, whereas there is a much lower correlation between the two glaciers of the Gran Paradiso Group, which suggests that differences in local topo-climatic factors can be decisive on such small ice bodies (e.g., Kuhn, 1995; DeBeer and Sharp, 2009; Carturan et al., 2013c; Scotti et al., 2014; Colucci and Guglielmin, 2015).

For most glaciers, $B_{\mathrm{a}}$ is more correlated to $B_{\mathrm{s}}$ than to $B_{\mathrm{w}}$ (Table 4), which further confirms the importance of summer 

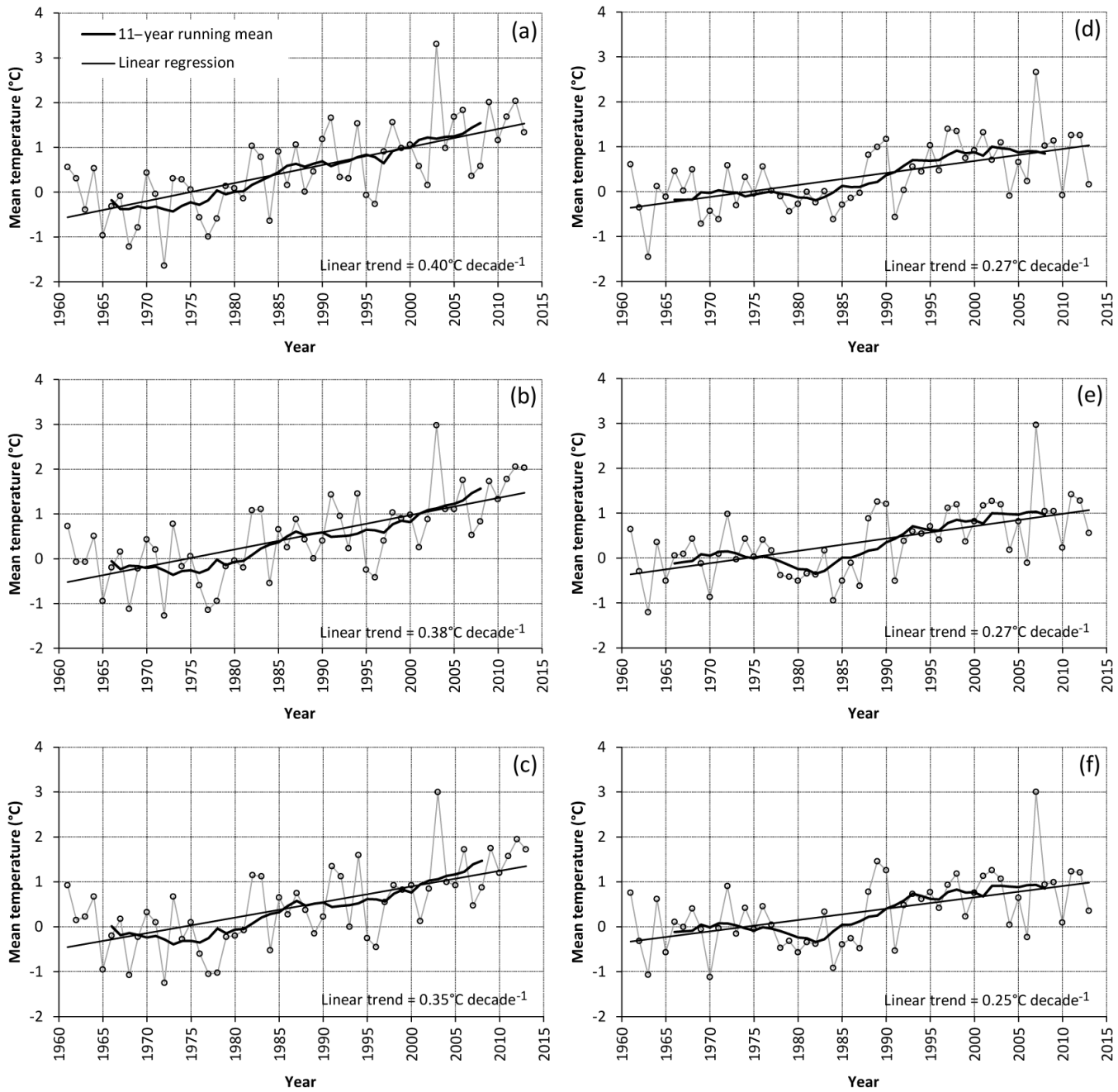

Figure 5. Left column: mean ablation season (Jun-Sep) air temperature anomalies in (a) Gran Paradiso, (b) Ortles-Cevedale and (c) Val Ridanna. Right column: mean accumulation season (Oct-May) air temperature anomalies in (d) Gran Paradiso, (e) Ortles-Cevedale and (f) Val Ridanna. Reference period: 1961-1990. All linear trends are significant at the 0.001 level.

ablation. The relevance of the snow redistribution and overaccumulation on the Pendente and Grand Etrèt glaciers is indicated by the higher correlation of their $B_{\mathrm{a}}$ with $B_{\mathrm{w}}$. On La Mare Glacier, the two seasonal components have similar correlations with $B_{\mathrm{a}}$. However, these results are influenced by the length of the observation period and the presence/absence of extreme years with high accumulation (e.g., 2001) or high ablation (e.g., 2003) in the observation series of individual glaciers. For the analyzed glaciers, no significant correlation was found between $B_{\mathrm{S}}$ and $B_{\mathrm{w}}$.

\subsection{Climatic controls}

In the period from 1961 to 2013, there are highly significant warming trends for the Jun-Sep air temperature (Fig. 5a, b and c); they are highest in the Gran Paradiso Group $\left(0.40^{\circ} \mathrm{C}\right.$ decade $\left.^{-1}\right)$ and lowest in Val Ridanna $\left(0.35^{\circ} \mathrm{C}\right.$ decade $\left.^{-1}\right)$. The three phases in the longer $B_{\mathrm{a}}$ and

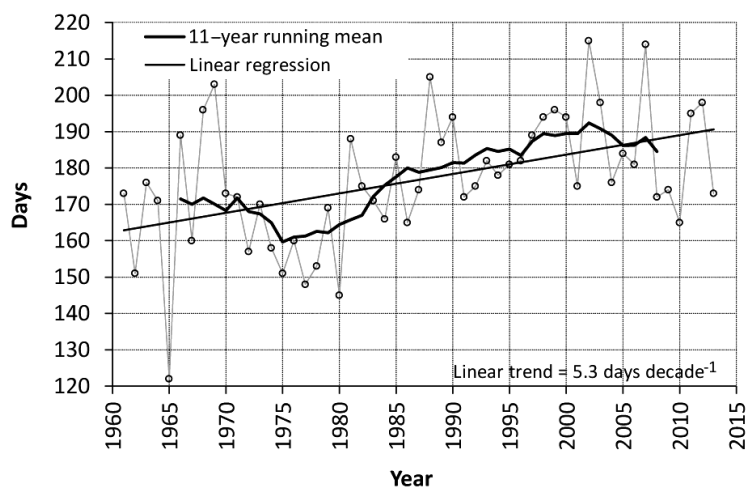

Figure 6. Days per year with maximum air temperature exceeding $0{ }^{\circ} \mathrm{C}$ at $3000 \mathrm{~m}$ a.s.l., calculated from the series of the Careser Diga weather station (2600 m a.s.l., Ortles-Cevedale Group). 
$B_{\mathrm{S}}$ series of glaciers (Fig. 3) can be recognized as periods with stationary Jun-Sep temperature, separated by switches in the early 1980s and after the peak of 2003. The warming trends are lower in the accumulation season and range from 0.25 to $0.27^{\circ} \mathrm{C}$ decade ${ }^{-1}$ (Fig. $5 \mathrm{~d}$, e and f), but thermal inversions at the valley weather stations could have partially masked the warming at the altitude of the glaciers in this season. The transition towards higher Oct-May temperature occurred in the late $1980 \mathrm{~s}$, after a minimum in the first half of the same decade. A distinct warm peak in Oct-May temperature occurred in 2007. The warming trend led to increased duration of the ablation period. The number of days per year with maximum temperature exceeding $0^{\circ} \mathrm{C}$, extrapolated at $3000 \mathrm{~m}$ a.s.l. from the series of the Careser Diga weather station ( $2600 \mathrm{~m}$ a.s.l. in the Ortles-Cevedale Group) with a lapse rate of $-0.65^{\circ} \mathrm{C} / 100 \mathrm{~m}$, increased from $160-170$ in the 1960s-1970s to about 190 in the late 1990s and 2000s (Fig. 6).

The precipitation does not show any significant trend in the accumulation season (Fig. 7d, e and f). The moving averages display oscillations of 10-20\% above and below the 19611990 mean, which lasted approximately 10-15 years and were higher in the Gran Paradiso Group than in the OrtlesCevedale and Val Ridanna. Periods with below-average precipitation are recognized in the 1960s, the first half of 1970s and the 1990s, whereas periods with above-average precipitation occurred in the second half of 1970s and the first half of 1980s. The last 10-15 years were characterized by precipitation close to the mean, with important maxima in 2001, 2009 and 2013 and minima in 2007 and 2012. Similarly to the findings from Durand et al. (2009a, b) and Eckert et al. (2011) for the French and western Swiss Alps, change points in winter precipitation of Ortles-Cevedale and Val Ridanna series were identified in 1977, corresponding to an increase of about $10-12 \%$. This finding is remarkable because, until present, this change point has been identified to have a rather regional significance limited to the western Alps. Linear trends of summer precipitation are positive but not statistically significant. The interannual variability of the JunSep precipitation is remarkably higher in the Gran Paradiso Group (Fig. 7a, b and c).

Large-scale circulation patterns, such as the NAO and the Northern Hemisphere blocking frequency, are connected to the temporal and spatial variability of winter precipitation in the Alps (Quadrelli et al., 2001). Several studies highlighted contrasting behavior of precipitation anomalies in the Oct-May period between the northern and southern Alps, i.e., opposite correlation with indexed large-scale circulation patterns (e.g., Quadrelli et al., 2001; Schmidli et al., 2002; Brunetti et al., 2006) and opposite long-term trends in the seasonal precipitation totals (e.g., Brunetti et al., 2006, 2009; Auer et al., 2007). This characteristic, as well as the tendency towards a decreasing NAO index in the last 2 decades (Fig. 8) that leads to increased winter precipitation in the southern side of the Alps, may provide an additional explanation for the different behavior of "European" and "Italian" glaciers shown in Fig. 4. Opposite effects of the NAO on the winter precipitation and glacier mass balance in the northern and southern parts of the Eastern Alps were also reported, for example, by Marzeion and Nesje (2012).

Our correlation analysis confirms that prevailing negative correlation exists between the $B_{\mathrm{w}}$ of Italian glaciers and the NAO in the accumulation season, whereas positive correlations prevail in other nations (Table 5) with the exception of Gries Glacier, which is close to the Italian border. The winter precipitation anomalies of the three geographic areas where the Italian mass balance glaciers are located (Sect. 2) are also anti-correlated with the winter NAO (Spearman correlation significant at the 0.01 level). In line with the findings of Reichert et al. (2001), Six et al. (2001) and Thibert et al. (2013), a negative correlation was calculated between $B_{\mathrm{s}} / B_{\mathrm{a}}$ and the NAO in the accumulation season. For the Italian glaciers the albedo feedback from wet/dry winters (with low/high NAO, respectively) can at least partly explain this behavior. For glaciers in other countries, however, given the prevailing positive correlation of their $B_{\mathrm{w}}$ with the winter NAO, the link between $B_{\mathrm{S}} / B_{\mathrm{a}}$ and the winter NAO is not so obvious and deserves additional analysis.

The examination of meteorological series confirms that increased ablation and the related feedbacks are the main causes of the increased imbalance of the analyzed Italian glaciers, as observed in Sect. 4.1. This result is further corroborated by the higher correlation of $B_{\mathrm{a}}$ with the Jun-Sep temperature than with the Oct-May precipitation, at least for the glaciers with longer observation series (Careser, Fontana Bianca, Sforzellina and Ciardoney; Table 6). $B_{\mathrm{a}}$ of glaciers with shorter observation series is not significantly correlated with the Jun-Sep temperature; instead, two of them (La Mare and Lunga) show a correlation with the Oct-May precipitation. Combining the Oct-May precipitation and Jun-Sep temperature in a multiple linear regression model leads to highly significant coefficients for both variables, even when the single seasonal components are not correlated with $B_{\mathrm{a}}$ (e.g., for the Pendente and La Mare glaciers). Approximately two-thirds of the $B_{\mathrm{a}}$ variance can be explained by the multiple linear regression. The poorest results were obtained for the two glaciers in Val Ridanna (Pendente and Malavalle) and the Grand Etrèt Glacier. As the first two glaciers are close to the main Alpine divide, they likely benefit from the high orographic uplift that locally enhances precipitation (Schwarb, 2000) but cannot be accounted for by the multiple regression model due to the lack of weather stations in that area. In addition, the multiple regression model does not account for accumulation by wind-borne snow on the Pendente and Grand Etrèt glaciers.

The Careser, Fontana Bianca and Pendente glaciers display significant negative correlations between their $B_{\mathrm{a}}$ and the Oct-May temperature. For the Careser Glacier, there is also a negative correlation between $B_{\mathrm{w}}$ and the Oct-May temperature. Normally, in this period, most precipitation 

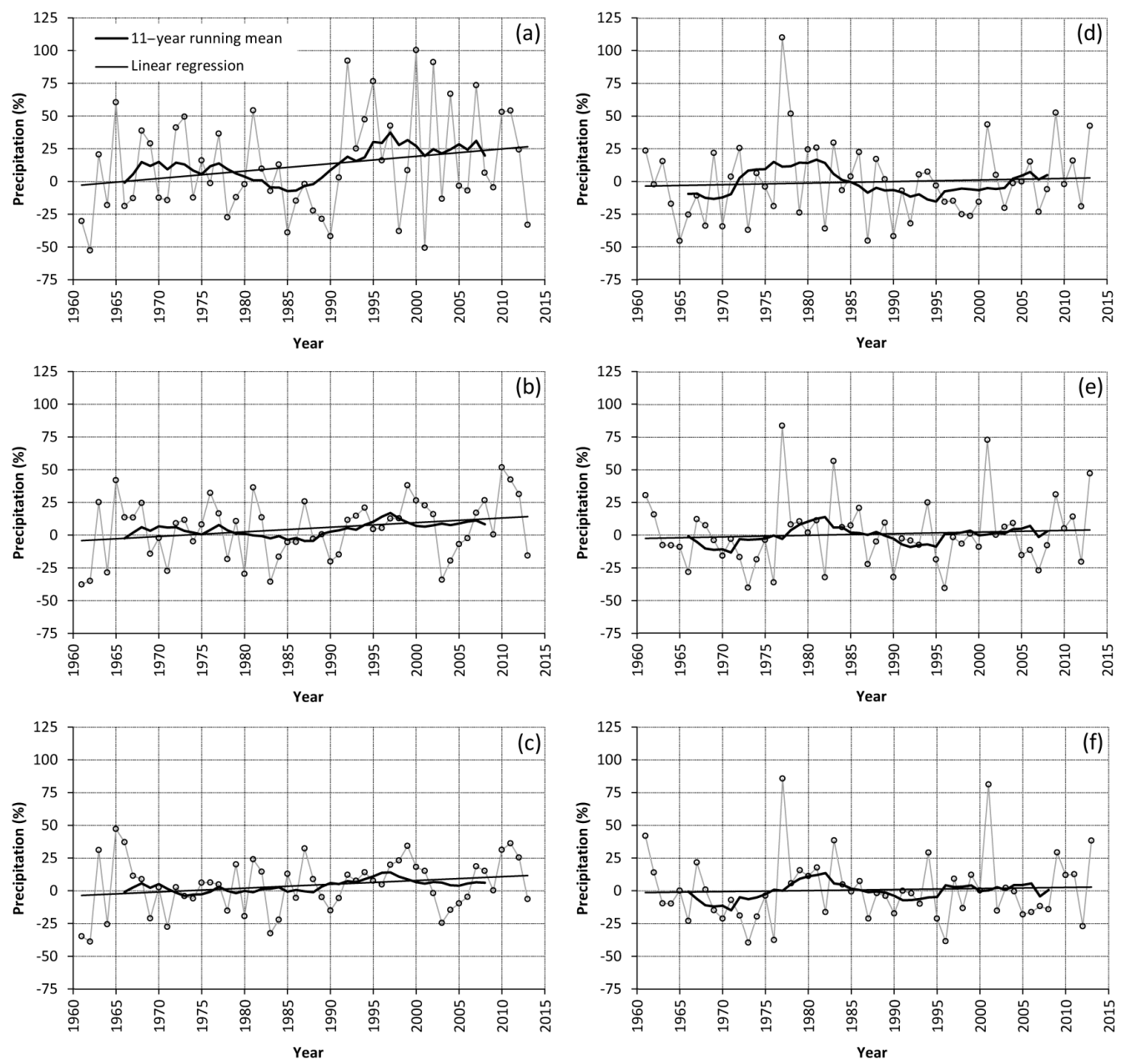

Figure 7. Left column: ablation season (Jun-Sep) total precipitation anomalies in (a) Gran Paradiso, (b) Ortles-Cevedale and (c) Val Ridanna. Right column: accumulation season (Oct-May) total precipitation anomalies in (d) Gran Paradiso, (e) Ortles-Cevedale and (f) Val Ridanna. Reference period: 1961-1990. None of the linear trends is significant at the 0.05 level.

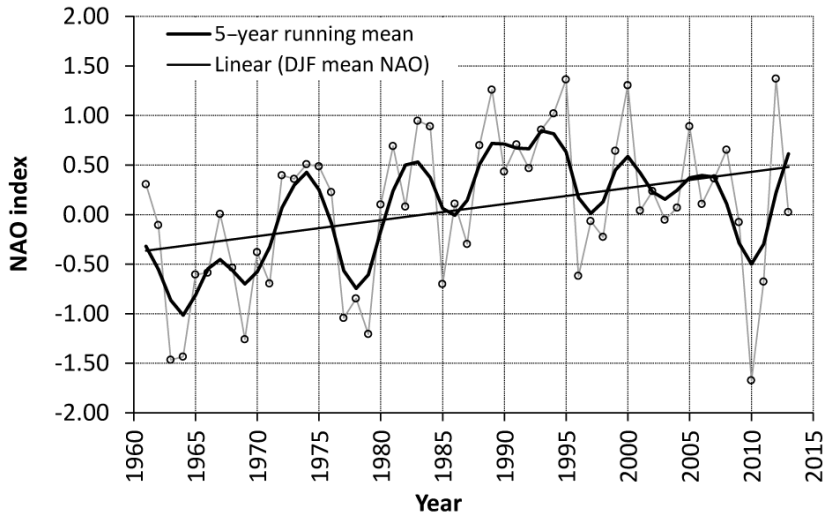

Figure 8. Winter NAO index from 1961 to 2013 (http://www.cpc. ncep.noaa.gov/products/precip/CWlink/pna/new.nao.shtml, last access: 11 February 2016). falls as snow, and the glaciers have negligible ablation and low temperature sensitivity (Oerlemans and Reichert, 2000). However, increasing temperature starts to lead to significant ablation in this period, especially in early and late winter, and reduce the fraction of solid precipitation as clearly detectable in the ablation season (Carturan et al., 2013b). An emblematic example is the warm accumulation season of 2006-2007, when the liquid precipitation reached 3000$3100 \mathrm{~m}$ a.s.l. (24 October 2006) and ice ablation exceeded $50 \mathrm{~cm}$ at $3000 \mathrm{~m}$ a.s.l. on the Careser and La Mare glaciers.

The correlation between $B_{\mathrm{a}}$ of Careser Glacier and the Oct-May temperature starts to become significant in the late 1980 s, as shown in the moving correlation analyses (30-year time window in Fig. 9). In the first 20 years, the correlation was absent or not statistically significant. These results are consistent with the discussed effects of increasing temperature on the ablation and partitioning between liquid and solid precipitation (Beniston et al., 2003). Reducing the window 
Table 5. Correlation coefficients of $B_{\mathrm{W}}, B_{\mathrm{S}}$ and $B_{\mathrm{a}}$ versus seasonal and annual NAO. Five-year triangular moving averages have been applied to the time series before correlation analyses.

\begin{tabular}{|c|c|c|c|c|c|c|c|c|c|c|}
\hline \multirow[b]{2}{*}{ Nation } & \multirow[b]{2}{*}{ Glacier } & \multicolumn{3}{|c|}{ Winter balance } & \multicolumn{3}{|c|}{ Summer balance } & \multicolumn{3}{|c|}{ Annual balance } \\
\hline & & DJF NAO & Oct-May NAO & Annual NAO & DJF NAO & Oct-May NAO & Annual NAO & DJF NAO & Oct-May NAO & Annual NAO \\
\hline I & Car & $-0.51^{b}$ & -0.34 & -0.16 & -0.23 & -0.05 & 0.34 & $-0.30^{\mathrm{a}}$ & -0.13 & 0.23 \\
\hline I & FB & -0.11 & 0.18 & 0.00 & 0.22 & 0.10 & 0.25 & 0.07 & 0.35 & $0.41^{\mathrm{a}}$ \\
\hline I & Pen & -0.70 & $-0.90^{\mathrm{a}}$ & -0.70 & $-1.00^{\mathrm{b}}$ & $-0.90^{\mathrm{a}}$ & $-1.00^{\mathrm{b}}$ & 0.12 & 0.15 & 0.23 \\
\hline I & $\mathrm{Cia}$ & 0.17 & 0.34 & 0.19 & -0.03 & 0.10 & 0.27 & 0.13 & 0.27 & 0.36 \\
\hline I & $\mathrm{GE}$ & $-0.81^{\mathrm{c}}$ & $-0.74^{b}$ & $-0.79^{\mathrm{b}}$ & $-0.88^{\mathrm{c}}$ & $-0.76^{b}$ & $-0.91^{\mathrm{c}}$ & $-0.86^{\mathrm{c}}$ & $-0.76^{b}$ & $-0.83^{\mathrm{c}}$ \\
\hline I & Lun & $-0.94^{b}$ & $-0.94^{b}$ & $-0.94^{b}$ & $-0.94^{b}$ & -0.77 & $-0.94^{b}$ & $-0.89^{\mathrm{b}}$ & $-0.83^{\mathrm{a}}$ & $-0.89^{\mathrm{b}}$ \\
\hline I & Mar & $-1.00^{\mathrm{c}}$ & $-0.89^{\mathrm{b}}$ & $-1.00^{\mathrm{c}}$ & 0.14 & 0.03 & 0.14 & $-0.79^{b}$ & $-0.82^{b}$ & $-0.89^{\mathrm{c}}$ \\
\hline I & Mal & $-0.90^{\mathrm{a}}$ & -0.70 & $-0.90^{\mathrm{a}}$ & -0.50 & -0.80 & -0.50 & $-0.81^{\mathrm{c}}$ & $-0.74^{b}$ & -0.45 \\
\hline I & Sfo & & & & & & & $0.59^{\mathrm{c}}$ & $0.59^{\mathrm{c}}$ & $0.61^{\mathrm{c}}$ \\
\hline $\mathrm{F}$ & St. Sorlin & & & & & & & $-0.44^{\mathrm{c}}$ & $-0.38^{\mathrm{c}}$ & -0.04 \\
\hline $\mathrm{F}$ & Sarennes & $0.36^{\mathrm{c}}$ & $0.43^{\mathrm{c}}$ & $0.49^{\mathrm{c}}$ & $-0.53^{c}$ & $-0.50^{\mathrm{c}}$ & -0.19 & $-0.41^{\mathrm{c}}$ & $-0.37^{\mathrm{c}}$ & -0.05 \\
\hline $\mathrm{CH}$ & Silvretta & $0.28^{\mathrm{a}}$ & 0.13 & -0.05 & $-0.57^{c}$ & $-0.45^{\mathrm{c}}$ & -0.18 & $-0.38^{\mathrm{c}}$ & $-0.28^{b}$ & 0.02 \\
\hline $\mathrm{CH}$ & Gries & $-0.39^{\mathrm{c}}$ & -0.22 & -0.18 & $-0.58^{\mathrm{c}}$ & $-0.53^{\mathrm{c}}$ & $-0.25^{\mathrm{a}}$ & $-0.49^{c}$ & $-0.39^{c}$ & -0.03 \\
\hline A & Sonnblick & & & & & & & $-0.48^{\mathrm{c}}$ & $-0.45^{\mathrm{c}}$ & -0.07 \\
\hline A & Vernagt & $0.27^{\mathrm{a}}$ & $0.51^{\mathrm{c}}$ & $0.49^{\mathrm{c}}$ & $-0.42^{\mathrm{c}}$ & $-0.38^{b}$ & -0.09 & $-0.36^{b}$ & $-0.26^{\mathrm{a}}$ & 0.07 \\
\hline A & Kesselwand & & & & & & & $-0.42^{\mathrm{c}}$ & $-0.38^{\mathrm{c}}$ & -0.07 \\
\hline A & Hintereis & & & & & & & $-0.55^{\mathrm{c}}$ & $-0.44^{\mathrm{c}}$ & -0.10 \\
\hline
\end{tabular}

Table 6. Spearman correlation coefficients and multiple regression results of $B_{\mathrm{a}}$ versus seasonal mean temperature and precipitation.

\begin{tabular}{|c|c|c|c|c|c|c|c|c|c|}
\hline \multicolumn{10}{|c|}{ Air temperature - correlation coefficients } \\
\hline & Car & FB & Sfo & $\mathrm{Cia}$ & Pen & GE & Mal & Mar & Lun \\
\hline No. of years & 47 & 27 & 27 & 22 & 18 & 12 & 12 & 11 & 10 \\
\hline Jun-Sep & $-0.77^{\mathrm{c}}$ & $-0.49^{\mathrm{b}}$ & $-0.52^{\mathrm{b}}$ & $-0.64^{\mathrm{b}}$ & -0.40 & 0.01 & -0.24 & -0.16 & 0.49 \\
\hline Oct-May & $-0.37^{\mathrm{b}}$ & $-0.42^{\mathrm{a}}$ & -0.10 & -0.18 & $-0.49^{\mathrm{a}}$ & -0.18 & -0.57 & -0.28 & -0.33 \\
\hline Year & $-0.68^{\mathrm{c}}$ & $-0.49^{b}$ & -0.30 & $-0.49^{\mathrm{a}}$ & $-0.69^{b}$ & -0.31 & $-0.71^{b}$ & -0.27 & -0.14 \\
\hline \multicolumn{10}{|c|}{ Precipitation - correlation coefficients } \\
\hline & Car & FB & Sfo & $\mathrm{Cia}$ & Pen & GE & Mal & Mar & Lun \\
\hline No. of years & 47 & 27 & 27 & 22 & 18 & 12 & 12 & 11 & 10 \\
\hline Jun-Sep & -0.15 & -0.02 & 0.09 & 0.20 & 0.00 & 0.02 & -0.04 & 0.26 & -0.05 \\
\hline Oct-May & 0.28 & $0.40^{\mathrm{a}}$ & 0.32 & $0.47^{\mathrm{a}}$ & 0.37 & 0.57 & 0.43 & $0.67^{\mathrm{a}}$ & $0.71^{\mathrm{a}}$ \\
\hline Year & 0.11 & 0.36 & $0.39^{\mathrm{a}}$ & $0.53^{\mathrm{a}}$ & 0.34 & $0.64^{\mathrm{a}}$ & 0.34 & $0.83^{\mathrm{b}}$ & 0.53 \\
\hline \multicolumn{10}{|c|}{ Multiple linear regression - coefficients } \\
\hline & Car & FB & Sfo & $\mathrm{Cia}$ & Pen & GE & Mal & Mar & Lun \\
\hline No. of years & 47 & 27 & 27 & 22 & 18 & 12 & 12 & 11 & 10 \\
\hline Jun-Sep temperature & $-776.453^{c}$ & $-663.487^{c}$ & $-575.225^{\mathrm{c}}$ & $-796.739^{c}$ & $-496.521^{b}$ & -63.899 & -355.106 & $-668.941^{b}$ & 115.265 \\
\hline Oct-May precipitation & $2.186^{\mathrm{c}}$ & $3.342^{\mathrm{c}}$ & $2.915^{\mathrm{c}}$ & $3.315^{\mathrm{c}}$ & $2.380^{\mathrm{a}}$ & $2.897^{\mathrm{b}}$ & $3.051^{\mathrm{a}}$ & $4.122^{b}$ & $2.666^{\mathrm{a}}$ \\
\hline Intercept & $-3265.013^{\mathrm{c}}$ & $-3311.632^{\mathrm{c}}$ & $-3176.797^{\mathrm{c}}$ & 1753.826 & 1011.719 & -2707.559 & 19.212 & $-3380.905^{\mathrm{c}}$ & $-2619.872^{b}$ \\
\hline$\%$ of explained variance & 75.6 & 68.7 & 72.1 & 73.7 & 51.5 & 56.8 & 56.0 & 78.4 & 64.5 \\
\hline
\end{tabular}

a-c indicate $0.05,0.01$ and 0.001 significance levels.

size from 30 to 15 years leads to a noisier signal and in this case the correlation between $B_{\mathrm{a}}$ and Oct-May temperature does not reach the $95 \%$ significance thresholds. However, it is interesting to remark the reversal of the correlation sign from positive in the first years to negative in the last years.

The four glaciers in Fig. 9 (Careser, Fontana Bianca, Sforzellina and Ciardoney) share a common trend towards (i) a non-significant moving correlation between $B_{\mathrm{a}}$ and the Jun-Sep temperature and (ii) a significant moving correlation between $B_{\mathrm{a}}$ and Oct-May precipitation. This behavior is probably related to the snow-rich accumulation seasons of
2001, 2009 and 2013 and to the fact that the ablation season is already so warm that (i) summer snow falls mostly above the highest reaches of the glaciers, which reduces the interannual variability of summer melt, and (ii) conditions close to balanced budget only occur after snow-rich accumulation seasons.

Rapid geometric changes may also lead to a nonlinear response of $B_{\mathrm{a}}$ to atmospheric changes, at least for some glaciers (Elsberg et al., 2001; Paul, 2010). For example, the multiple regression residuals of the Careser Glacier, which were mostly positive in the 1980s, 1990s and 2000s, became 

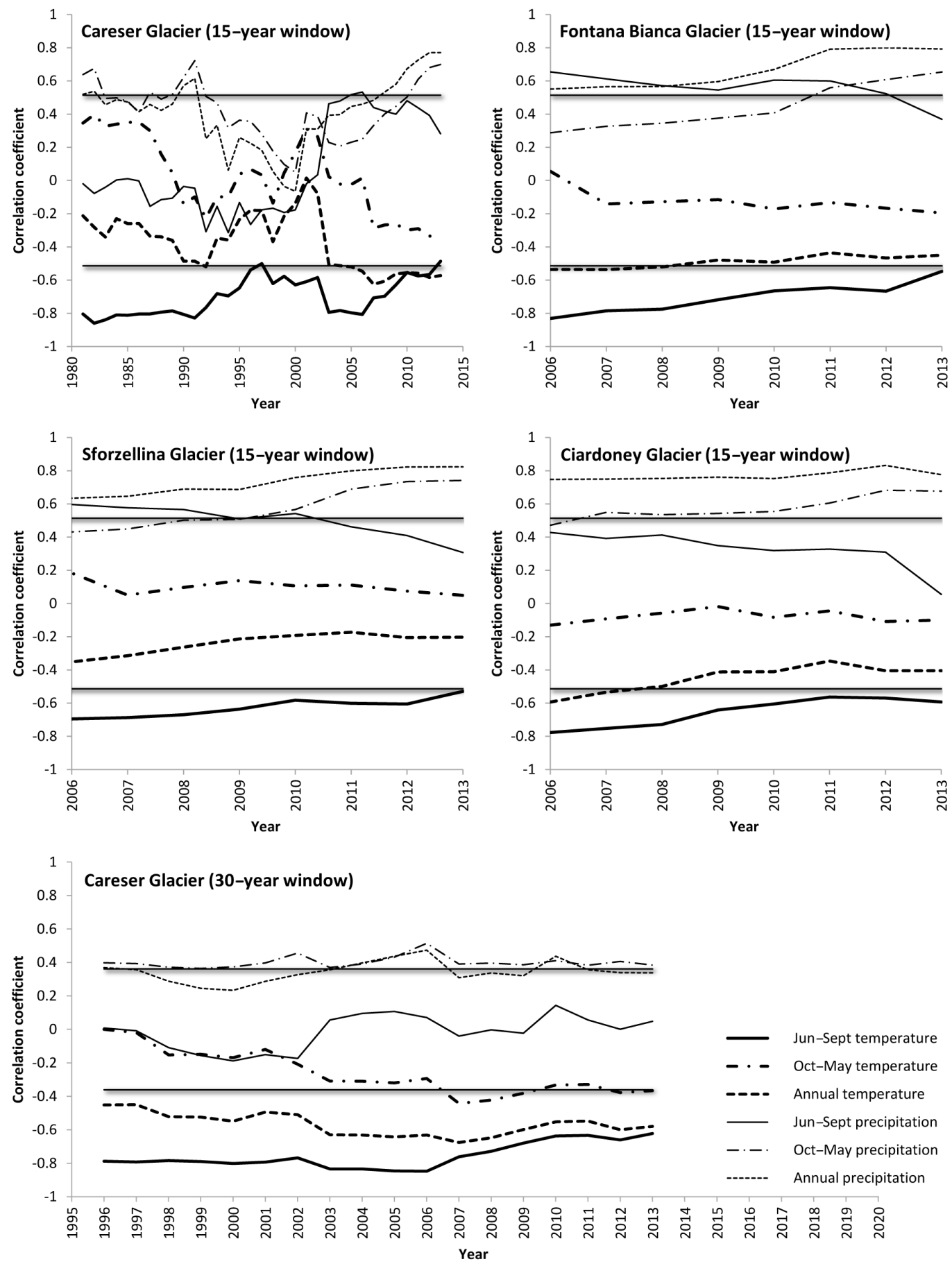

Figure 9. Bootstrapped moving correlation coefficient between annual mass balance and seasonal values of air temperature and precipitation. Shaded straight lines indicate significance at $95 \%$ level.

predominantly negative after 2008 (Fig. 10). This change may suggest that the rapid modifications occurred in the latest years could have induced a negative feedback, reducing the mass loss rate of the glacier, whose current surface and shape are strongly different from the recent past (inset in Fig. 10). Because the multiple regression model does not use the Oct-May temperature as an explanatory variable, it cannot account for the effects of the warm accumulation season of 2006-2007, which led to a very low $B_{\mathrm{w}}$, early disappearance of winter snow and positive albedo feedback. Therefore, the year 2007 results in highly positive regression residuals. 


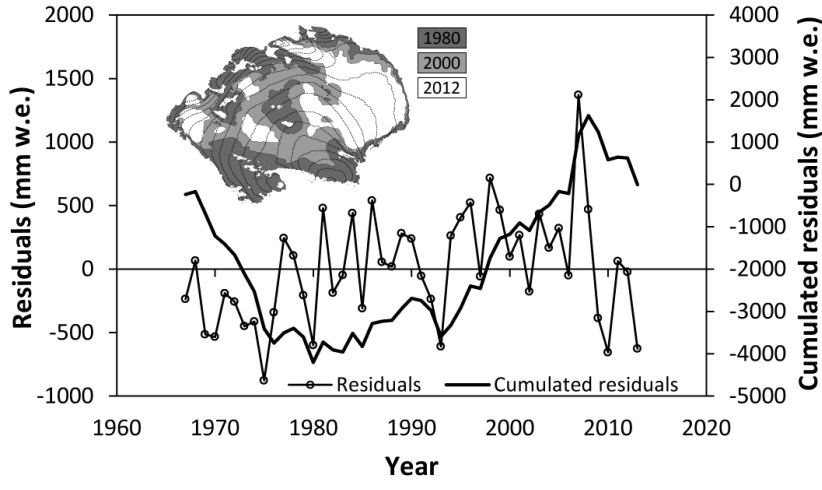

Figure 10. Plot of residuals of the multiple linear regression of $B_{\mathrm{a}}$ versus Oct-May precipitation and Jun-Sep temperature on the Careser Glacier. Multiple regression coefficients are reported in Table 6 . The inset shows the extent of the glacier in three different years.

\subsection{Future requirements}

A common characteristic for all glaciers analyzed is their very low mean AAR in the last decade (Table 2). Accumulation areas were almost nonexistent in most glaciers, indicating that they will soon disappear, even without additional warming. Some glaciers are displaying morphological changes that indicate their impending extinction, such as rapid disintegration (e.g., Careser Glacier; Fig. 10) and surface lowering in the upper accumulation area (e.g., Fontana Bianca Glacier). The AARs of approximately 0.25 indicate that accumulation areas still exist in the larger and higherreaching La Mare and Malavalle glaciers. However, given that balanced-budget conditions require AAR close to 0.55, large mass loss and area reduction are also expected for these two glaciers to reach equilibrium with the climatic conditions of the last 10 years.

The forthcoming vanishing of the monitored glaciers puts the continuation of their mass balance observations at risk. Recently started monitoring programs in larger and higherreaching glaciers, such as Malavalle and La Mare, will ensure continued observations in Val Ridanna and the OrtlesCevedale. In line with the recommendations from the WGMS (Zemp et al., 2009), parallel observation programs of replacing/replaced glaciers should start in other large and highreaching glaciers of the Italian Alps, e.g., in the Gran Paradiso group (to substitute Ciardoney and Grand Etrèt) and in other mountain groups. Both the initiation of observations over new glaciers and the replacement of vanishing glaciers will require an assessment of the spatial representativeness of single glaciers through the comparison of the current mass loss rates over wide geographic areas (Haeberli et al., 2013). This assessments can be obtained using modern techniques, such as the multi-temporal differencing of digital elevation models, which enable the comparison of mass loss rates in the last years/decades, by means of the geodetic method, over entire regions or mountain ranges (e.g., Paul and Haeberli, 2008; Abermann et al., 2011; Carturan et al., 2013b; Berthier et al., 2014; Fischer et al., 2015). The geodetic mass balance should also help to control the glacier-wide $B_{\mathrm{a}}$ series measured with the direct glaciological method and to construct a constant-geometry mass balance record (Elsberg et al., 2001) to be connected to climatic drivers.

\section{Conclusions}

In this work, we have analyzed the time series of the glaciers with mass balance observations in the Italian Alps. Based on the results of the analyses, the following conclusions can be drawn.

- All examined glaciers are experiencing imbalanced conditions, and the longer series show sustained negative trends of $B_{\mathrm{a}}$.

- The observed behavior was mainly caused by increased ablation, led by warmer temperature and related feedbacks, such as the lengthening of the ablation season. The total precipitation does not show any significant trend, but the fraction of solid precipitation decreased as a consequence of the warmer temperature.

- The $B_{\mathrm{a}}$ of the analyzed glaciers is mainly correlated to $B_{\mathrm{s}}$, except for two glaciers where wind-borne snow enhances the importance of $B_{\mathrm{w}}$. For most glaciers, approximately two-thirds of the $B_{\mathrm{a}}$ variance can be explained by multiple linear regression, using the Oct-May precipitation and Jun-Sep temperature as independent variables.

- The monitored Italian glaciers have comparable mass loss rates to a sample of representative glaciers of the entire European Alps. However, the moving correlation analyses and time series of residuals from multiple linear regressions suggest that the smaller (and thinner) Italian glaciers may be reacting faster to atmospheric changes.

- Large-scale circulation patterns, such as the NAO, have opposite effects in the northern and southern sides of the European Alps. Most of the Italian mass balance series are anti-correlated to the synoptic signal held by the NAO index, through both winter and summer components, sometimes with a strong link. However, in some cases the link is weak or absent and there is not a clear spatial structure.

- Most monitored glaciers have no more accumulation area and are at risk of extinction, even without additional warming. Therefore, they will soon require a replacement with larger and higher glaciers that retain accumulation areas. 
- Regional assessments of the mass loss rates using the geodetic method are required to identify possible replacing glaciers, evaluate their spatial representativeness and enable the transitions from replaced to replacing glaciers, as suggested by Haeberli et al. (2013).

Author contributions. M. Brunetti processed the meteorological data and prepared the synthetic meteorological series used in this work. T. Zanoner compiled the database of the mass balance data and geometric characteristics of the glaciers. L. Carturan and G. Zuecco performed the temporal and statistical analyses of the mass balance series. L. Carturan prepared the manuscript with contributions from all co-authors.

Acknowledgements. This study was funded by the Italian MIUR Project (PRIN 2010-11), "Response of morphoclimatic system dynamics to global changes and related geomorphological hazards" (local and national coordinators G. Dalla Fontana and C. Baroni) and by the research grant "Impact of climatic fluctuations on snowand ice-dominated alpine watersheds: effects on the cryosphere and hydrology" (University of Padova-Department of Land, Environment, Agriculture and Forestry). The authors acknowledge the regional environmental agencies of Piemonte, Val d'Aosta, Lombardia and the autonomous provinces of Trento and Bolzano, which provided the meteorological and topographic data used in this study. Many thanks to Stephan Galos (University of Innsbruck) for sharing information on glaciers in Ötztal and South Tyrol. We would also like to thank all investigators and contributing institutions for the collection and free exchange of the glacier mass balance series. Etienne Berthier, Emmanuel Thibert and an anonymous referee provided useful suggestions in the review process.

Edited by: E. Berthier

\section{References}

Abermann, J., Lambrecht, A., Fischer, A., and Kuhn, M.: Quantifying changes and trends in glacier area and volume in the Austrian Ötztal Alps (1969-1997-2006), The Cryosphere, 3, 205215, doi:10.5194/tc-3-205-2009, 2009.

Abermann, J., Kuhn, M., and Fischer, A.: Climatic controls of glacier distribution and glacier changes in Austria, Ann. Glaciol., 52, 83-90, 2011.

Auer, I., Böhm, R., Jurkovic, A., Lipa, W., Orlik, A., Potzmann, R., Schöner, W., Ungersböck, M., Matulla, C., Briffa, K., Jones, P., Efthymiadis, D., Brunetti, M., Nanni, T., Maugeri, M., Mercalli, L., Mestre, O., Moisselin, J.-M., Begert, M., Müller-Westermeier, G., Kveton, V., Bochnicek, O., Stastny, P., Lapin, M., Szalai, S., Szentimrey, T., Cegnar, T., Dolinar, M., Gajic-Capka, M., Zaninovic, K., Majstorovic, Z., and Nieplova, E.: HISTALP - Historical Instrumental climatological Surface Time series of the greater ALPine Region, Int. J. Climatol., 27, 17-46, doi:10.1002/joc.1377, 2007.
Baroni, C., Bondesan, A., and Mortara, G.: Report of the Glaciological Survey of 2011 - relazioni della campagna glaciologica 2011, Geogr. Fis. Din. Quat., 35, 211-279, doi:10.4461/GFDQ.2012.35.19, 2012.

Baroni, C., Bondesan, A., and Mortara, G.: Report of the Glaciological Survey of 2012 - relazioni della campagna glaciologica 2012, Geogr. Fis. Din. Quat., 36, 303-374, doi:10.4461/GFDQ.2013.36.24, 2013.

Baroni, C., Bondesan, A., and Mortara, G.: Report of the Glaciological Survey 2013, relazioni della Campagna Glaciologica 2013, Geogr. Fis. Din. Quat., 37, 163-227, doi:10.4461/GFDQ.2014.37.16, 2014.

Beniston, M., Keller, F., Koffi, B., and Goyette, S.: Estimates of snow accumulation and volume in the Swiss Alps under changing climatic conditions, Theor. Appl. Climatol., 76, 125-140, doi:10.1007/s00704-003-0016-5, 2003.

Benn, D. I. and Evans, D. J. A. (Eds.): Glaciers and Glaciation, Hodder Education, London, UK, 802 pp., 2010.

Berthier, E., Vincent, C., Magnússon, E., Gunnlaugsson, Á. P., Pitte, P., Le Meur, E., Masiokas, M., Ruiz, L., Pálsson, F., Belart, J. M. C., and Wagnon, P.: Glacier topography and elevation changes derived from Pléiades sub-meter stereo images, The Cryosphere, 8, 2275-2291, doi:10.5194/tc-8-2275-2014, 2014.

Braithwaite, R. J. and Olesen, O. B.: Detection of climate signal by inter-stake correlations of annual ablation data Qamanârssûp Sermia, West Greenland, J. Glaciol., 35, 253-259, 1989.

Brunetti, M., Maugeri, M., Nanni, T., Auer, I., Böhm, R., and Schöner, W.: Precipitation variability and changes in the Greater Alpine region over the 1800-2003 period, J. Geophys. Res., 111, D11107, doi:10.1029/2005JD006674, 2006.

Brunetti, M., Lentini, G., Maugeri, M., Nanni, T., Auer, I., Böhm, R., and Schöner, W.: Climate variability and change in the Greater Alpine Region over the last two centuries based on multi-variable analysis, Int. J. Climatol., 29, 2197-2225, doi:10.1002/joc.1857, 2009.

Brunetti, M., Lentini, G., Maugeri, M., Nanni, T., Simolo, C., and Spinoni, J.: Projecting North Eastern Italy temperature and precipitation secular records onto a high resolution grid, Phys. Chem. Earth, 40, 9-22, doi:10.1016/j.pce.2009.12.005, 2012.

Brunetti, M., Maugeri, M., Nanni, T., Simolo, C., and Spinoni, J.: High-resolution temperature climatology for Italy: interpolation method intercomparison, Int. J. Climatol., 34, 1278-1296, doi:10.1002/joc.3764, 2014.

Cannone, N., Diolaiuti, G., Guglielmin, M., and Smiraglia, C.: Accelerating climate change impacts on alpine glacier forefield ecosystems in the European Alps, Ecol. Appl., 18, 637-648, doi:10.1890/07-1188.1, 2008.

Carturan, L., Baroni, C., Becker, M., Bellin, A., Cainelli, O., Carton, A., Casarotto, C., Dalla Fontana, G., Godio, A., Martinelli, T., Salvatore, M. C., and Seppi, R.: Decay of a long-term monitored glacier: Careser Glacier (Ortles-Cevedale, European Alps), The Cryosphere, 7, 1819-1838, doi:10.5194/tc-7-1819-2013, 2013a.

Carturan, L., Filippi, R., Seppi, R., Gabrielli, P., Notarnicola, C., Bertoldi, L., Paul, F., Rastner, P., Cazorzi, F., Dinale, R., and Dalla Fontana, G.: Area and volume loss of the glaciers in the Ortles-Cevedale group (Eastern Italian Alps): controls and imbalance of the remaining glaciers, The Cryosphere, 7, 13391359, doi:10.5194/tc-7-1339-2013, 2013b. 
Carturan, L., Baldassi, G. A., Bondesan, A., Calligaro, S., Carton, A., Cazorzi, F., Dalla Fontana, G., Francese, R., Guarnieri, A., Milan, N., Moro, D., and Tarolli, P.: Current behavior and dynamics of the lowermost Italian glacier (Montasio Occidentale, Julian Alps), Geogr. Ann. A, 95, 79-96, doi:10.1111/geoa.12002, 2013c.

Casartelli, G., Kappenberger, G., and Smiraglia, C.: Accumulo e ablazione sui ghiacciai delle alpi lombarde e svizzere: Risultati di alcuni recenti bilanci di massa, Rivista Geografica Italiana, 103, 1-30, 1996.

Catasta, G. and Smiraglia, C.: The mass balance of a cirque glacier in the Italian Alps (Ghiacciaio della Sforzellina, Ortles-Cevedale Group), J. Glaciol., 39, 87-90, 1993.

CGI (Comitato Glaciologico Italiano): Reports of the Glaciological Surveys, Bollettino del Comitato Glaciologico Italiano, Torino, Series I and II, 1-25, 1914-1977.

CGI (Comitato Glaciologico Italiano): Reports of the glaciological surveys, Geogr. Fis. Din. Quat., 1-35, 1978-2011.

Cogley, J. G.: Geodetic and direct mass-balance measurements: comparison and joint analysis, Ann. Glaciol., 50, 96-100, 2009.

Cogley, J. G. and Adams, W. P.: Mass balance of glaciers other than the ice sheets, J. Glaciol., 44, 315-325, 1998.

Cogley, J. G., Hock, R., Rasmussen, L. A., Arendt, A. A., Bauder, A., Braithwaite, R. J., Jansson, P., Kaser, G., Moller, M., Nicholson, L., and Zemp, M.: Glossary of Glacier Mass Balance and Related Terms, IHP-VII Technical Documents in Hydrology No. 86, IACS Contribution No. 2, UNESCO-IHP, Paris, 2011.

Colucci, R. R. and Guglielmin, M.: Precipitation-temperature changes and evolution of a small glacier in the southeastern European Alps during the last 90 years, Int. J. Climatol., 35, 27832797, doi:10.1002/joc.4172, 2015.

Debeer, C. M. and Sharp, M. J.: Topographic influences on recent changes of very small glaciers in the Monashee Mountains, British Columbia, Canada, J. Glaciol., 55, 691-700, doi:10.3189/002214309789470851, 2009.

Durand, Y., Laternser, M., Giraud, G., Etchevers, P., Lesaffre, B., and Mérindol, L.: Reanalysis of 44 years of climate in the French Alps (1958-2002): methodology, model validation, climatology, and trends for air temperature and precipitation, J. Appl. Meteorol. Climatol., 48, 429-449, 2009a.

Durand, Y., Giraud, G., Laternser, M., Etchevers, P., Mérindol, L., and Lesaffre, B.: Reanalysis of 47 years of climate in the French Alps (1958-2005): climatology and trends for snow cover, J. Appl. Meteorol. Climatol., 48, 2487-2512, 2009b.

Dyurgerov, M., Meier, M. F., and Bahr, D. B.: A new index of glacier area change: a tool for glacier monitoring, J. Glaciol., 55, 710-716, 2009.

Eckert, N., Baya, H., Thibert, E., and Vincent, C.: Extracting the temporal signal from a winter and summer mass-balance series: application to a six-decade record at Glacier de Sarennes, French Alps, J. Glaciol., 57, 134-150, 2011.

Elsberg, D. H., Harrison, W. D., Echelmeyer, K. A., and Krimmel, R. M.: Quantifying the effect of climate and surface change on glacier mass balance, J. Glaciol., 47, 649-658, 2001.

Fischer, M., Huss, M., and Hoelzle, M.: Surface elevation and mass changes of all Swiss glaciers 1980-2010, The Cryosphere, 9, 525-540, doi:10.5194/tc-9-525-2015, 2015.
Furbish, D. J. and Andrews, J. T.: The use of hypsometry to indicate long-term stability and response of valley glaciers to changes in mass transfer, J. Glaciol., 30, 199-211, 1984.

Galos, S. P., Klug, C., Prinz, R., Rieg, L., Dinale, R., Sailer, R., and Kaser, G.: Recent glacier changes and related contribution potential to river discharge in the Vinschgau/Val Venosta, Italian Alps, Geogr. Fis. Din. Quat., 38, 143-154, doi:10.4461/GFDQ.2015.38.13, 2015.

Haeberli, W., Huggel, C., Paul, F., and Zemp, M.: Glacial responses to climate change, in: Treatise on Geomorphology, 13, Academic Press, San Diego, California, 152-175, 2013.

Hoelzle, M., Haeberli, W., Dischl, M., and Peschke, W.: Secular glacier mass balances derived from cumulative glacier length changes, Global Planet. Change, 36, 295-306, doi:10.1016/S0921-8181(02)00223-0, 2003.

Huss, M., Dhulst, L., and Bauder, A.: New long-term mass balance series for the Swiss Alps, J. Glaciol., 61, 551-562, doi:10.3189/2015JoG15j015, 2015.

Kaser, G., Fountain, A., and Jansson, P.: A Manual for Monitoring the Mass Balance of Mountain Glaciers, IHP-VI Technical Documents in Hydrology No. 59, UNESCO-IHP, Paris, 2003.

Killick, R. and Eckley, I. A.: Changepoint: An R package for changepoint analysis, J. Stat. Softw., 58, 1-19, doi:10.18637/jss.v058.i03, 2014.

Kuhn, M.: The mass balance of very small glaciers, Zeitschrift für Gletscherkunde und Glazialgeologie, 31, 171-179, 1995.

Lliboutry, L.: Multivariate statistical analysis of glacier annual balances, J. Glaciol., 13, 371-392, 1974.

Marzeion, B. and Nesje, A.: Spatial patterns of North Atlantic Oscillation influence on mass balance variability of European glaciers, The Cryosphere, 6, 661-673, doi:10.5194/tc-6-6612012, 2012.

Mernild, S. H., Lipscomb, W. H., Bahr, D. B., Radic, V., and Zemp, M.: Global glacier changes: a revised assessment of committed mass losses and sampling uncertainties, The Cryosphere, 7, 1565-1577, doi:10.5194/tc-7-1565-2013, 2013.

Mitchell, T. D. and Jones, P. D.: An improved method of constructing a database of monthly climate observations and associated high-resolution grids, Int. J. Climatol., 25, 693-712, doi:10.1002/joc.1181, 2005.

New, M., Hulme, M., and Jones, P. D.: Representing twentieth century space-time variability, Part 2: development of 1901-96 monthly grids of surface climate, J. Climate, 13, 2217-2238, 2000.

Oerlemans, J. and Reichert, B. K.: Relating glacier mass balance to meteorological data by using a seasonal sensitivity characteristic, J. Glaciol., 46, 1-6, doi:10.3189/172756500781833269, 2000.

Østrem, G. and Brugman, M.: Mass Balance Measurement Techniques, a Manual for Field and Office Work, National Hydrological Research Institute (NHRI), Science Report, 4, Saskatoon, Canada, 224 pp., 1991.

Paul, F. and Haeberli, W.: Spatial variability of glacier elevation changes in the Swiss Alps obtained from two digital elevation models, Geophys. Res. Lett., 35, L21502, doi:10.1029/2008GL034718, 2008.

Paul, F.: The influence of changes in glacier extent and surface elevation on modeled mass balance, The Cryosphere, 4, 569-581, doi:10.5194/tc-4-569-2010, 2010. 
Pelto, M. S.: Glacier annual balance measurement, forecasting and climate correlations, North Cascades, Washington 1984-2006, The Cryosphere, 2, 13-21, doi:10.5194/tc-2-13-2008, 2008.

Quadrelli, R., Lazzeri, M., Cacciamani, C., and Tibaldi, S.: Observed winter Alpine precipitation variability and links with large-scale circulation patterns, Clim. Res., 17, 275-284, doi:10.3354/cr017275, 2001.

Reichert, B. K., Bengtsson, L., and Oerlemans, J.: Midlatitude forcing mechanisms for glacier 25 mass balance investigated using general circulation models, J. Climate, 14, 3767-3784, 2001.

Salvatore, M. C., Zanoner, T., Baroni, C., Carton, A., Banchieri, F. A., Viani, C., Giardino, M., and Perotti, L.: The state of Italian glaciers: a snapshot of the 2006-2007 hydrological period, Geogr. Fis. Dinam. Quat., 38, 175-198, 2015.

Schmidli, J., Schmutz, C., Frei, C., Wanner, H., and Schär, C.: Mesoscale precipitation variability in the region of the European Alps during the 20th century, Int. J. Climatol., 22, 1049-1074, doi:10.1002/joc.769, 2002.

Schöner, W., Auer, I., and Böhm, R.: Climate variability and glacier reaction in the Austrian eastern Alps, Ann. Glaciol., 31, 31-38, 2000.

Schwarb, M.: The Alpine Precipitation Climate, PhD thesis, ETH Zürich, Zürich, Switzerland, 131 pp., 2000.

Scotti, R., Brardinoni, F., and Crosta, G. B.: Post-LIA glacier changes along a latitudinal transect in the Central Italian Alps, The Cryosphere, 8, 2235-2252, doi:10.5194/tc-8-2235-2014, 2014.

Six, D., Reynaud, L., and Letréguilly, A.: Alpine and Scandinavian glaciers mass balances, their relations with the North Atlantic Oscillation, Comptes Rendus de l'Académie des Sciences, Series IIA, Earth Planet. Sc., 333, 693-698, 2001.

Thibert, E., Eckert, N., and Vincent, C.: Climatic drivers of seasonal glacier mass balances: an analysis of 6 decades at Glacier de Sarennes (French Alps), The Cryosphere, 7, 47-66, doi:10.5194/tc-7-47-2013, 2013.

Vincent, C., Kappenberger, G., Valla, F., Bauder, A., Funk, M., and Le Meur, E.: Ice ablation as evidence of climate change in the Alps over the 20th century, J. Geophys. Res., 109, D10104, doi:10.1029/2003JD003857, 2004.

WGMS: Global Glacier Changes: Facts and Figures, edited by: Zemp, M., Roer, I., Kaab, A., Hoelzle, M., Paul, F., and Haerberli, W., UNEP, World Glacier Monitoring Service, Zürich, Switzerland, 2008.
WGMS: Fluctuations of Glaciers 2005-2010, Volume X, edited by: Zemp, M., Frey, H., Gärtner-Roer, I., Nussbaumer, S. U., Hoelzle, M., Paul, F., and W. Haeberli, ICSU(WDS)/IUGG(IACS)/UNEP/UNESCO/WMO, World Glacier Monitoring Service, Zurich, Switzerland, 336 pp., publication based on database version: doi:10.5904/wgms-fog2012-11, 2012.

WGMS: Glacier Mass Balance Bulletin No. 12 (2010-2011), edited by: Zemp, M., Nussbaumer, S. U., Naegeli, K., Gärtner-Roer, I., Paul, F., Hoelzle, M., and Haeberli, W., ICSU(WDS)/IUGG(IACS)/UNEP/UNESCO/WMO, World Glacier Monitoring Service, Zurich, Switzerland, 106 pp., publication based on database version: doi:10.5904/wgms-fog2013-11, 2013.

WGMS: Fluctuations of Glaciers Database, World Glacier Monitoring Service, Zurich, Switzerland, publication based on database version: doi:10.5904/wgms-fog-2015-11, 2015.

Zemp, M., Frauenfelder, R., Haeberli, W., and Hoelzle, M.: Worldwide glacier mass balance measurements: general trends and first results of the extraordinary year 2003 in Central Europe, Data of Glaciological Studies [Materialy glyatsiologicheskih issledovanii], Moscow, Russia, 99, 3-12, 2005.

Zemp, M., Paul, F., Hoelzle, M., and Haeberli, W.: Glacier fluctuations in the European Alps 1850-2000: an overview and spatio-temporal analysis of available data, in: The Darkening Peaks: Glacial Retreat in Scientific and Social Context, edited by: Orlove, B., Wiegandt, E., and Luckman, B. H., University of California Press, Berkeley, 152-167, 2008.

Zemp, M., Hoelzle, M., and Haeberli, W.: Six decades of glacier mass-balance observations: a review of the worldwide monitoring network, Ann. Glaciol., 50, 101-111, doi:10.3189/172756409787769591, 2009.

Zemp, M., Thibert, E., Huss, M., Stumm, D., Rolstad Denby, C., Nuth, C., Nussbaumer, S. U., Moholdt, G., Mercer, A., Mayer, C., Joerg, P. C., Jansson, P., Hynek, B., Fischer, A., Escher-Vetter, H., Elvehøy, H., and Andreassen, L. M.: Reanalysing glacier mass balance measurement series, The Cryosphere, 7, 12271245, doi:10.5194/tc-7-1227-2013, 2013. 